\title{
Synthesis and Cytotoxic Profile of 3,4-Methylenedioxymethamphetamine ("Ecstasy") and Its Metabolites on Undifferentiated PC12 Cells: A Putative Structure-Toxicity Relationship
}

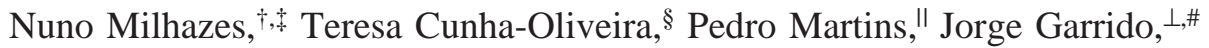 \\ Catarina Oliveira, ${ }^{\S}$ A. Cristina Rego, ${ }^{\S}$ and Fernanda Borges* $*, l, \perp$ \\ CEQOFFUP, Faculdade de Farmácia, Universidade do Porto, 4050-047 Porto, Portugal, Instituto Superior \\ Ciências da Saúde-Norte, 4585-116 Gandra, PRD, Portugal, Instituto de Bioquímica, Faculdade de Medicina e \\ Centro de Neurociências e Biologia Celular de Coimbra, Universidade de Coimbra, 3004-504 Coimbra, \\ Portugal, Departamento de Química Orgânica, Faculdade de Farmácia, Universidade do Porto, \\ 4050-047 Porto, Portugal, Unidade I\&D “Química-Física Molecular”, and Departamento de Engenharia \\ Química, Instituto Superior de Engenharia do Porto, IPP, Porto, Portugal
}

Received June 7, 2006

\begin{abstract}
The toxicological and redox profiles of MDMA and its major metabolites (MDA, $\alpha$-methyldopamine, $N$-methyl- $\alpha$-methyldopamine, 6-hydroxy- $\alpha$-methyldopamine, 3-methoxy- $\alpha$-methyldopamine) were studied to establish a structure-toxicity relationship and determine their individual contribution to cell death induction by apoptosis and/or necrosis. The results of the comparative toxicity study, using undifferentiated PC12 cells, strongly suggest that the metabolites possessing a catecholic group are more toxic to the cells than MDMA and metabolites with at least one protected phenolic group. Redox studies reveal that an oxidative mechanism seems to play an important role in metabolite cytotoxicity. Nuclear features of apoptosis and/or necrosis show that most of the metabolites, particularly $N$-methyl- $\alpha$-methyldopamine, induce cell death by apoptosis, largely accompanied by necrotic features. No significant differences were found between MDMA and the metabolites, concerning overall characteristics of cell death. These results may be useful to ascertain the contribution of metabolism in MDMA neurotoxicity molecular mechanisms.
\end{abstract}

\section{Introduction}

3,4-Methylenedioxymethamphetamine (MDMA, "ecstasy", 16) is a ring-substituted phenethylamine derivative widely used as a recreational drug. The abuse of this group of amphetaminelike designer drugs is increasing among young adults, being at present a serious public health problem $(1,2)$. The toxicity related to the misuse of this drug is extensively reported in recent literature, but the molecular mechanisms involved remain largely unknown. Among several biological targets, the neurotoxic (3), nephrotoxic (4), hepatotoxic (5), and cardiovascular (6) effects of MDMA were extensively studied in vitro and in vivo.

The research on the biotransformation reactions of xenobiotics, which play a major role in influencing the nature, intensity, and duration of wanted and unwanted effects, is an important task in the medicinal chemistry field (7). A majority of the investigation has been based on the overall effects induced by the use of the drug, but little attention has been given to the putative activities of the metabolites themselves. Several recent studies suggest that part of the toxicity ascribed to MDMA can be related to the formation of metabolites with higher activity $(8-10)$. Several MDMA metabolic pathways have been proposed and reported (11-12), with the $N$-demethylation to 3,4-

* Corresponding author. Tel: +351222078900. Fax: +351222003977. E-mail: fborges@ff.up.pt.

CEQOFFUP, Universidade do Porto.

* Instituto Superior Ciências da Saúde - Norte.

$\S$ Universidade de Coimbra.

"Departamento de Química Orgânica, Universidade do Porto.

${ }^{\perp}$ Unidade I\&D "Química-Física Molecular".

\# Instituto Superior de Engenharia do Porto. methylenedioxyamphetamine (MDA, 11), also as a recreational drug, and the simultaneous or subsequent $O$-demethylenation to 3,4-dihydroxyamphetamine ( $\alpha$-methyldopamine, $\alpha$-MeDA, $19)$ and 3,4-dihydroxymethamphetamine ( $N$-methyl- $\alpha$-methyldopamine, $N$-Me- $\alpha-M e D A, 21)$ being the most significant ones. It has also been assumed that the catecholic compounds 19 and 21 can undergo subsequent $O$-methylation mediated by catechol $O$-methyltranferase (COMT) to 4-hydroxy-3-methoxyamphetamine (3-methoxy- $\alpha$-methyldopamine, $3-O-\mathrm{Me}-\alpha-\mathrm{MeDA}, 13$ ) and 4-hydroxy-3-methoxymethamphetamine (Figure 1).

Aromatic hydroxylation has also been established as an important biotransformation step in in vivo metabolism of MDMA in rats. This reaction can occur at the remaining positions of the aromatic ring, but the one occurring at $\mathrm{C}_{6}$ is the most reactive one. The resulting compound 2,4,5-trihydroxyamphetamine (6hydroxy- $\alpha$-methyldopamine, $6-\mathrm{OH}-\alpha-\mathrm{MeDA}, 20)$ is structurally similar to 6-hydroxydopamine (a potent neurotoxin obtained by in vivo aromatic hydroxylation of dopamine) $(13,14)$. All compounds possessing a catecholic group can undergo further conjugation with other molecules like sulfate, glucuronide and thiol-containing endogenous substances (glutathione, cysteine, and $\mathrm{N}$-acetylcysteine).

Animals exposed to MDMA show acute and long-term neurotoxic effects, causing irreversible damage to the central nervous system. Characterization of the in vivo and in vitro MDMA-induced neurotoxicity was widely accomplished (15-17), although the molecular mechanisms involved remain to be fully elucidated. Previously published studies suggested that bioactivation occurs after the administration of amphetamines, mediating a series of neurotoxic effects $(18-20)$. 


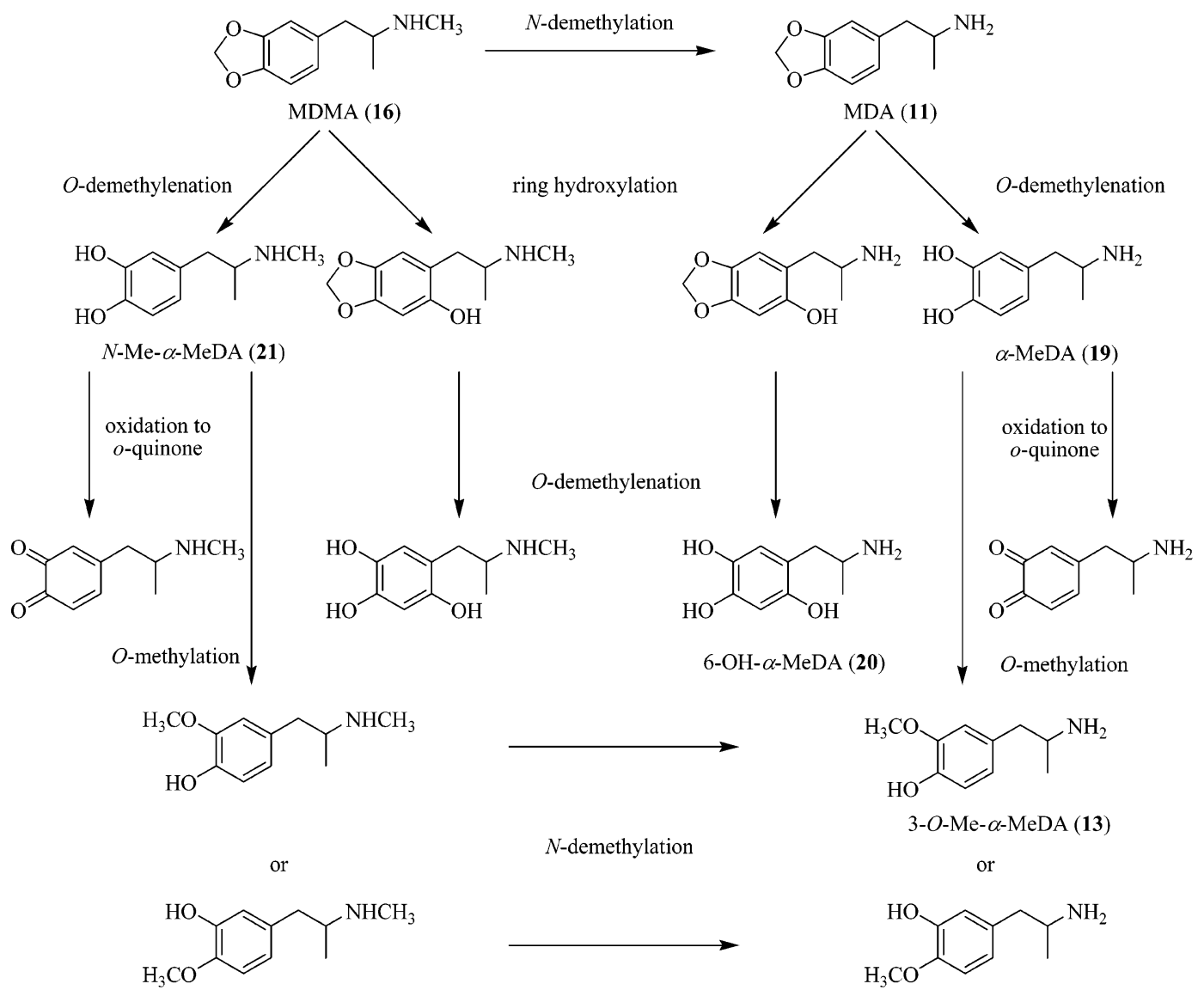

Figure 1. Proposed major metabolic pathways of MDMA; the numbered compounds correspond to the metabolites synthesized and used in the toxicological assays.

MDMA is a monoaminergic neurotoxin in both serotonin (5HT) and dopamine nerve terminals, depending on the animal species and conditions of administration. The neurotoxicity has been largely associated to a modification of the serotonergic function, namely, through an acute release of serotonin from central neurons, followed by prolonged depletion and structural neuronal damage $(21-23)$. There is also considerable evidence that MDMA shows marked effects on dopamine release and can damage dopamine axon terminals, which could play a major role in some behavioral, mental, and thermal changes in animals $(24,25)$.

Cell death by apoptosis or necrosis has been proposed to be involved in amphetamine-induced neurodegeneration $(26,27)$. The activation of these pathways seems to be closely related to the occurrence of oxidative stress in the cellular medium, through redox cycles, which is intimately linked to the metabolism of MDMA and catecholamine (auto)oxidation $(10,28)$.

Nonconjugated metabolites of MDMA are present in blood, brain, liver, feces, and urine for a 24-hour period following drug administration (11). It is generally accepted that one or more metabolites of MDMA or MDA may be responsible for neurotoxic effects because direct intracerebral injection of the drugs failed to reproduce the neurotoxicity revealed after peripheral administration (29). As MDMA does not seem to be neurotoxic, the evaluation of the metabolite's toxic effects is essential for the elucidation of the molecular mechanisms involved. However, there is controversy regarding the specific role of the metabolites. Intracerebroventricular administration of $\alpha$-MeDA, $N$-Me- $\alpha-M e D A$, and 3- $O$-Me- $\alpha-M e D A$ failed to produce the same neurotoxic features on central serotoninergic and dopaminergic systems induced by peripherally administered MDMA $(18,30)$; nonetheless, other neurochemical effects were determined, and alterations were detected for the same metabolites, specially for 6-OH- $\alpha-\operatorname{MeDA}(18,31,32)$.

In order to examine the hypothesis that the metabolites can contribute to the neurotoxicity of the parent compound, the cytotoxic potential of MDMA and five of its metabolites was investigated. The research project includes the synthesis of the main described metabolites of MDMA through standard synthetic methods and the evaluation of their cytotoxic profiles by using undifferentiated PC12 cells in culture, a well-established in vitro model of catecholaminergic neurons (33-35). Cell viability was assessed after incubation for $24 \mathrm{~h}$ with increasing concentrations of the compounds in order to determine the $\mathrm{IC}_{50}$ values. Because oxidative pathways have been proposed to play an important role in the toxicity profile of this type of compounds, the relationship between the redox profile and cytotoxicity was also studied. Accordingly, to get new insights on the molecular mechanisms underlying the biological activities, the redox properties of the drug and metabolites were determined using different electrochemical techniques.

Because MDMA-induced cell damage is related to programmed cell death in serotoninergic and neocortical neurons $(36,37)$, assays of chromatin fragmentation/condensation were performed in PC12 cells in order to define drug-induced cell death as apoptotic and/or necrotic. To the best of our knowledge, there are no reports of apoptosis-like events induced by the MDMA metabolites in dopaminergic-like neurons.

\section{Experimental Procedures}

Materials and Solutions. PC12 cells were obtained from ATCC (Manassas, VA). 3,4-Dihydroxybenzaldehyde, 3,4-dimethoxybenzaldehyde, 4-hydroxy-3-methoxybenzaldehyde, 2,4,5- trimethoxy- 
benzaldehyde, bromochloromethane, potassium carbonate, benzyl chloride, cesium carbonate, ammonium acetate, nitroethane, anhydrous magnesium sulfate, lithium aluminum hydride (1 M solution in tetrahydrofuran), ethyl chloroformate, boron tribromide (1 M solution in dichloromethane), $10 \%$ platinum in carbon, RPMI 1640 medium (modified with L-glutamine and $25 \mathrm{mM}$ HEPES), streptomycin, penicillin, MTT, poly-L-lysine and propidium iodide, and all dry solvents were purchased from Sigma-Aldrich Química S.A. (Sintra, Portugal). Syto-13 was obtained from Molecular Probes (Eugene, OR). Horse serum and fetal bovine serum were purchased from BioChrom KG (Berlin, Germany). All other reagents and solvents were pro analysis grade and were acquired from Merck (Lisbon, Portugal). Deionized water (conductivity $<0.1 \mu \mathrm{S} \mathrm{cm}^{-1}$ ) was used in all experiments. The gases, hydrogen, argon and nitrogen, were of the highest grade available. All reagents were used without further purification.

To perform electrochemical measurements, $10 \mathrm{mM}$ stock solutions of the compounds were made by dissolving an appropriate amount in water. The voltammetric working solutions were prepared, in an electrochemical cell, by diluting $100 \mu \mathrm{L}$ of the stock solution in $10 \mathrm{~mL}$ of supporting electrolyte to get a final concentration of $0.1 \mathrm{mM}$. The $\mathrm{pH} 7.3$ supporting electrolyte, used for voltammetric determinations, was prepared by diluting $6.2 \mathrm{~mL}$ of $0.2 \mathrm{M}$ dipotassium hydrogen phosphate and $43.8 \mathrm{~mL}$ of $0.2 \mathrm{M}$ potassium dihydrogen phosphate to $100 \mathrm{~mL}$.

Apparatus and Other Analytical Conditions. ${ }^{1} \mathrm{H}$ and ${ }^{13} \mathrm{C}$ NMR data were acquired, at room temperature, on a Brüker AMX 300 spectrometer operating at 300.13 and $75.47 \mathrm{MHz}$, respectively. Chemical shifts are expressed in $\delta(\mathrm{ppm})$ values, relative to tetramethylsilane (TMS) (as internal reference); coupling constants $(J)$ are given in Hz. Dimethyl sulfoxide- $d_{6}$ was used as solvent unless specified in spectroscopic data. Assignments were also made from DEPT (distortionless enhancement by polarization transfer) experiments (values in italic). Electron impact mass spectra (EI-MS) were obtained on a VG AutoSpec instrument; data are reported as $\mathrm{m} / \mathrm{z}$ (\% of relative intensity for the most important fragments). Melting points were measured on a Köfler microscope (Reichert Thermovar) and were uncorrected. Analytical thin-layer chromatography (TLC) was carried out on $0.2 \mathrm{~mm}$ silica gel 60 F254 plates.

The purity of the final products ( $>95 \%$ purity) was verified using two different high-performance liquid chromatography (HPLC) systems, one equipped with a UV detector (DAD) and the other with an electrochemical detector. First, chromatograms were obtained in an HPLC/DAD system, a Jasco instrument (pumps model 880-PU and solvent mixing model 880-30, Tokyo, Japan), equipped with a commercially prepacked Nucleosil RP-18 analytical column $(250 \mathrm{~mm} \times 4.6 \mathrm{~mm}, 5 \mu \mathrm{m}$, Macherey-Nagel, Düren, Germany), and UV detection (Jasco model 875-UV) at the maximum wavelength determined by the analysis of the UV spectrum of each compound. The isocratic mobile phase consisted of $10 \mathrm{mM}$ aqueous ammonium acetate (adjusting the final $\mathrm{pH}$ to 3 with hydrochloric acid) with $10 \%$ acetonitrile, at a flow rate of 1 $\mathrm{mL} / \mathrm{min}$ at room temperature. The chromatographic data was processed in a Compaq computer, fitted with CSW 1.7 software (DataApex, Czech Republic).

A Waters 2690 Alliance system equipped with a CONCORDE Electrochemical Detector (Waters Corporation, Milford, USA) was also used. The electrochemical cell was a VT-03 flow cell (Antec Leyden, Zoeterwoude, Netherlands) with a confined wall-jet design in a three-electrode configuration: a $2 \mathrm{~mm}$ diameter glassy carbon working electrode, an in-situ $\mathrm{Ag} / \mathrm{AgCl}$ reference electrode, and a stainless steel auxiliary electrode. The electrochemical detector was operated in oxidative amperometric mode with the working potentials between $-100 \mathrm{mV}$ and $+1200 \mathrm{mV}$. The HPLC separation was carried out in a reverse phase LC-18-S Supelcosil analytical column $(150 \mathrm{~mm} \times 4.6 \mathrm{~mm}, 5 \mu \mathrm{m}$, Supelco, Bellefonte, USA); $100 \mathrm{mM}$ sodium acetate $(\mathrm{pH} 4.3) /$ methanol (10:3) was used as mobile phase, in isocratic mode at $1 \mathrm{~mL} / \mathrm{min}$ flow rate. Chromatograms were acquired in a Millenium 32 Chromatography Manager (Waters Corporation, Milford, USA).
Electrochemical data were obtained using an Autolab PGSTAT 12 potentiostat/galvanostat (Eco-Chemie, Netherlands) and a onecompartment glass electrochemical cell. Voltammetric curves were recorded at room temperature using a three-electrode system. A glassy carbon working electrode (GCE) $(d=2 \mathrm{~mm})$, a platinum wire counter electrode, and an $\mathrm{Ag} / \mathrm{AgCl}$ saturated $\mathrm{KCl}$ reference electrode were used. A Metrohm E520 pH-meter with glass electrode was used for $\mathrm{pH}$ measurements (Metrohm, Switzerland).

Synthesis of Metabolites. Synthesis of Aldehydes 1 and 5. 3,4Methylenedioxybenzaldehyde (1). Because piperonal (1) is not commercially available in Portugal, it was synthesized by an adaptation of a previously described procedure (38). The dioxole ring was closed after the reaction of the starting material 3,4benzaldehyde with bromochloromethane and using cesium carbonate as a catalyst.

3,4-Dibenzyloxybenzaldehyde (5). Briefly, 3,4-benzaldehyde or protocatechualdehyde $(5.0 \mathrm{~g}, 36.2 \mathrm{mmol})$ was dissolved in $\mathrm{N}, \mathrm{N}$ dimethylformamide (DMF) $(80 \mathrm{~mL})$. Potassium carbonate $(20.0 \mathrm{~g}$, $144.9 \mathrm{mmol})$ and benzyl chloride $(9.6 \mathrm{~mL}, 83.5 \mathrm{mmol})$ were then added to the solution, and the resulting suspension was stirred and refluxed for $5 \mathrm{~h}$. The remaining residue was filtered and the solution poured on cold water/ice and acidified with $\mathrm{HCl}(\mathrm{pH} 4)$. The yellow precipitate produced was filtered, washed with cold water, and identified as compound 5 (yield: $96 \%$ ). The spectroscopic data is in accordance with an article published earlier (39).

General Synthetic Procedure for Obtaining $\beta$-Methyl- $\beta$ nitrostyrenes $(6-10)$. The synthetic method used to obtain these compounds was an adaptation of references published earlier (38, $40,41)$ with only minor modifications. The corresponding benzaldehyde (1-5), with the aromatic substitution pattern of the target compound, $(30.0 \mathrm{mmol})$ and ammonium acetate $(7.5 \mathrm{mmol})$ were dissolved in nitroethane $(50 \mathrm{~mL})$ and refluxed for $6 \mathrm{~h}$. After cooling the reaction mixtures to room temperature, the solvent was partially evaporated, diluted with diethyl ether, and washed twice with 100 $\mathrm{mL}$ of water. The organic layers were dried over anhydrous magnesium sulfate, filtered, and concentrated. The remaining residues were recrystallized from diethylether/petroleum ether $\left(40-60{ }^{\circ} \mathrm{C}\right)$ or from methanol/water to yield yellow to orange solids.

The reactions were all followed by thin layer chromatography (TLC). The synthesized $\beta$-methyl- $\beta$-nitrostyrene derivatives $(6-10)$ were identified by both NMR and EI-MS. The compounds were systematically characterized in this work, even though some of them had been previously reported $(11,42,43)$. The data of the remaining compound used in this study (6) is described elsewhere (44).

3,4-Dimethoxy- $\boldsymbol{\beta}$-methyl- $\boldsymbol{\beta}$-nitrostyrene (7). Yield $95 \%$; ${ }^{1} \mathrm{H}$ NMR $\delta: 2.44\left(3 \mathrm{H}, s, \mathrm{CH}_{3}\right), 3.80\left(3 \mathrm{H}, s, 3-\mathrm{OCH}_{3}\right), 3.82(3 \mathrm{H}, s$, 4- $\left.\mathrm{OCH}_{3}\right), 7.08(1 \mathrm{H}, d, J=8.5, \mathrm{H}(5)), 7.22(1 \mathrm{H}, s, \mathrm{H}(2)), 7.23$ $(1 \mathrm{H}, d, J=8.5, \mathrm{H}(6)), 8.08(1 \mathrm{H}, s, \mathrm{H}(\alpha)) ;{ }^{13} \mathrm{C} \mathrm{NMR} \delta: 14.0$ $\mathrm{CH}_{3}, 55.6\left(4-\mathrm{OCH}_{3}\right), 55.7\left(3-\mathrm{OCH}_{3}\right), 111.8,113.9 \mathrm{C}(2)$ and $\mathrm{C}$ $(5), 124.3 \mathrm{C}(6), 124.4 \mathrm{C}(1), 133.8 \mathrm{C}(\alpha), 145.6 \mathrm{C}(\beta), 148.7 \mathrm{C}(4)$, $150.7 \mathrm{C}(3)$; EI-MS m/z (\%): $223\left(\mathrm{M}^{+\bullet}, 100\right), 176$ (78), 165 (22), 161 (37), 146 (47), 131 (46), 119 (36), 103 (37), 91 (47), 77 (38), 65 (34); mp 71-72 ${ }^{\circ} \mathrm{C}$ (lit (43). mp 72-74 ${ }^{\circ} \mathrm{C}$ ).

4-Hydroxy-3-methoxy- $\boldsymbol{\beta}$-methyl- $\boldsymbol{\beta}$-nitrostyrene (8). Yield 98\%; ${ }^{1} \mathrm{H}$ NMR $\delta: 2.44\left(3 \mathrm{H}, s, \mathrm{CH}_{3}\right), 3.81\left(3 \mathrm{H}, s, \mathrm{OCH}_{3}\right), 6.89(1 \mathrm{H}, d$, $J=8.2, \mathrm{H}(5)), 7.12(1 \mathrm{H}, d d, J=8.2 ; 1.9, \mathrm{H}(6)), 7.20(1 \mathrm{H}, d, J$ $=1.9, \mathrm{H}(2)), 8.05(1 \mathrm{H}, s, \mathrm{H}(\alpha)), 9.85(1 \mathrm{H}, \mathrm{bs}, \mathrm{O} H) ;{ }^{13} \mathrm{C} \mathrm{NMR} \delta$ : 14.0 $\mathrm{CH}_{3}, 55.7\left(\mathrm{OCH}_{3}\right), 114.8,115.9 \mathrm{C}(2)$ and $\mathrm{C}(5), 123.0 \mathrm{C}(1)$, $124.8 \mathrm{C}(6), 134.2 \mathrm{C}(\alpha), 144.7 \mathrm{C}(\beta), 147.7 \mathrm{C}(4), 149.2 \mathrm{C}(3)$; EI-MS m/z (\%): $209\left(\mathrm{M}^{+\bullet}, 100\right), 162$ (81), 147 (53), 131 (33), 119 (30), 103 (84), 91 (56), 77 (36), 65 (32); mp 97-99 ${ }^{\circ} \mathrm{C}$ (lit (42). mp 100-101 $\left.{ }^{\circ} \mathrm{C}\right)$.

2,4,5-Trimethoxy- $\boldsymbol{\beta}$-methyl- $\boldsymbol{\beta}$-nitrostyrene (9). Yield $92 \% ;{ }^{1} \mathrm{H}$ NMR $\delta: 2.39\left(3 \mathrm{H}, s, \mathrm{CH}_{3}\right), 3.74\left(3 \mathrm{H}, s, 2-\mathrm{OCH}_{3}\right), 3.88(6 \mathrm{H}, s, 4-$ and 5- $\left.\mathrm{OCH}_{3}\right), 6.79(1 \mathrm{H}, s, \mathrm{H}(3)), 7.01(1 \mathrm{H}, s, \mathrm{H}(6)), 8.20(1 \mathrm{H}, s$, $\mathrm{H}(\alpha)) ;{ }^{13} \mathrm{C} \mathrm{NMR} \delta: 14.1 \mathrm{CH}_{3}, 56.0,56.2,56.4\left(3 \times \mathrm{OCH}_{3}\right), 97.5 \mathrm{C}$ (3), 111.1, 113.3 C (1) and C (6), $128.8 \mathrm{C}(\alpha), 142.5 \mathrm{C}(2), 145.1$ $\mathrm{C}(\beta), 152.5 \mathrm{C}(4), 153.9 \mathrm{C}(5)$; EI-MS m/z (\%): $253\left(\mathrm{M}^{+}, 100\right)$, 206 (64), 191 (40), 177 (36), 163 (19), 149 (15), 121 (17), 77 (16), 69 (16); mp 93-95 ${ }^{\circ} \mathrm{C}$. 
3,4-Dibenzyloxy- $\boldsymbol{\beta}$-Methyl- $\boldsymbol{\beta}$-nitrostyrene (10). Yield 79\%; ${ }^{1} \mathrm{H}$ NMR $\delta: 2.32\left(3 \mathrm{H}, s, \mathrm{CH}_{3}\right), 5.20\left(2 \mathrm{H}, s, 3-\mathrm{OCH}_{2}\right), 5.22(2 \mathrm{H}, s$, 4-OCH $\mathrm{OC}_{2}, 7.20(2 \mathrm{H}, m, \mathrm{H}(2)$ and $\mathrm{H}(5)), 7.33-7.45(11 \mathrm{H}, m$, phenyl and $\mathrm{H}(6)), 8.03(1 \mathrm{H}, s, \mathrm{H}(\alpha)) ;{ }^{13} \mathrm{C}$ NMR $\delta: 13.9 \mathrm{CH}_{3}, 69.8,70.0$ $\left(2 \times \mathrm{CH}_{2}\right), 113.9,116.2 \mathrm{C}(2)$ and $\mathrm{C}(5), 124.6 \mathrm{C}(1), 124.9 \mathrm{C}(6)$, 127.6-128.5 (10×CHAr), $133.5 C(\alpha), 136.9(2 \times C \mathrm{Ar}), 145.7 \mathrm{C}(\beta)$, $147.8 \mathrm{C}(3), 150.1 \mathrm{C}(4)$; EI-MS $m / z$ (\%): 375 (M $\left.{ }^{+\bullet}, 20\right), 284$ (8), 181 (10), 91 (100), 65 (13); mp $107-109{ }^{\circ} \mathrm{C}$ (lit (45). mp 103$\left.105^{\circ} \mathrm{C}\right)$.

General Synthetic Procedure for the Reduction of Nitrostyrene Intermediates. The method applied for the synthesis of compounds 11-15 was a modification of those described earlier $(40,45)$. Therefore, a solution of the appropriate $\beta$-methyl- $\beta$ nitrostyrene derivative $(\mathbf{6}-\mathbf{1 0})(8 \mathrm{mmol})$ in anhydrous tetrahydrofuran (THF) $(30 \mathrm{~mL})$ was added dropwise to a stirred suspension of lithium aluminum hydride $(20 \mathrm{mmol})$ in anhydrous THF (50 $\mathrm{mL}$ ) under nitrogen $\left(\mathrm{N}_{2}\right)$. The reaction was stirred, heated under reflux for $4 \mathrm{~h}$, and then allowed to cool to room temperature. The excess $\mathrm{LiAlH}_{4}$ was decomposed and the reaction quenched by the smooth addition of cold water/ice with vigorous stirring. The inorganic residue was removed by vacuum filtration; the solvent was dried under anhydrous magnesium sulfate, evaporated, and the residue diluted with diethyl ether and extracted with aqueous $\mathrm{HCl}$ $(3 \times 100 \mathrm{~mL}$ of a $2 \mathrm{M}$ solution). The acidic extract was alkalinized with a $\mathrm{NaOH}$ solution and extracted with diethyl ether $(3 \times 100$ $\mathrm{mL})$. The organic layer was dried over anhydrous magnesium sulfate, filtered and concentrated to yield light brown oils.

When necessary for the systematic characterization of the compounds, the phenethylamine derivatives were isolated as salts (due mainly to their stability and simple of handling). Hence, the hydrochloride salts were prepared by acidifying the remaining residues with methanolic or ethanolic $\mathrm{HCl}$ and diluting with diethyl ether to obtain a white or almost white solid.

The identification of several of the amphetamine derivatives (11-15) had been previously reported $(10,11,43,45-48)$. Nevertheless, some structural data was insufficiently accomplished, and the spectroscopic characterization was thoroughly performed in this work. For the accurate ${ }^{1} \mathrm{H}$ NMR assignment of the $\left(\mathrm{CH}_{2} \mathrm{CH}\right) \mathrm{CH}_{3}$ group in all of the amphetamine derivatives, the spectra were also acquired in $\mathrm{CDCl}_{3}$ and $\mathrm{D}_{2} \mathrm{O}$.

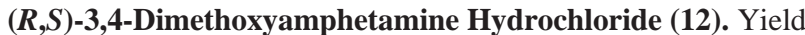
$56 \% ;{ }^{1} \mathrm{H}$ NMR $\delta: 1.11\left(3 \mathrm{H}, d, \mathrm{CH}_{3}\right), 2.61(1 \mathrm{H}, d d, J=13.4 ; 8.7$, $\left.\mathrm{CH}_{2}\right), 2.93\left(1 \mathrm{H}, d d, J=13.4 ; 5.4, \mathrm{CH}_{2}\right), 3.36(1 \mathrm{H}, m, \mathrm{CH}), 3.72$ $\left(3 \mathrm{H}, s, 3-\mathrm{OCH}_{3}\right), 3.75\left(3 \mathrm{H}, s, 4-\mathrm{OCH}_{3}\right), 6.73(1 \mathrm{H}, d d, J=8.1 ; 1.8$, $\mathrm{H}(6)), 6.85(1 \mathrm{H}, d, J=1.8, \mathrm{H}(2)), 6.89(1 \mathrm{H}, d, J=8.2, \mathrm{H}(5))$, $8.11\left(3 \mathrm{H}, \mathrm{bs}, \mathrm{NH}_{3}{ }^{+}\right) ;{ }^{13} \mathrm{C} \mathrm{NMR} \delta: 17.6 \mathrm{CH}_{3}, 39.6 \mathrm{CH}_{2}, 48.0 \mathrm{CH}$, $55.4,55.5\left(2 \times \mathrm{OCH}_{3}\right), 111.8,112.9 \mathrm{C}(2)$ and $\mathrm{C}(5), 121.2 \mathrm{C}(6)$, 129.0 C (1), $147.6 \mathrm{C}(3), 148.7 \mathrm{C}(4)$; EI-MS m/z (\%): $195\left(\mathrm{M}^{+\bullet}\right.$, 5), 162 (7), 152 (95), 137 (17), 121 (6), 107 (14), 91 (12), 83 (100), 65 (15); mp $146-148{ }^{\circ} \mathrm{C}$ (lit (43). mp $145-148{ }^{\circ} \mathrm{C}$ ).

$(R, S)$-4-Hydroxy-3-methoxyamphetamine Hydrochloride (13). Yield 35\%; ${ }^{1} \mathrm{H}$ NMR $\delta: 1.10\left(3 \mathrm{H}, d, \mathrm{CH}_{3}\right), 2.56(1 \mathrm{H}, d d, J=$ $\left.13.5 ; 8.6, \mathrm{CH}_{2}\right), 2.86\left(1 \mathrm{H}, d d, J=13.4 ; 5.5, \mathrm{CH}_{2}\right), 3.38(1 \mathrm{H}, m$, $\mathrm{CH}), 3.75\left(3 \mathrm{H}, s, 3-\mathrm{OCH}_{3}\right), 6.60(1 \mathrm{H}, d d, J=8.0 ; 1.8, \mathrm{H}(6))$, $6.72(1 \mathrm{H}, d, J=8.0, \mathrm{H}(5)), 6.79(1 \mathrm{H}, d, J=1.8, \mathrm{H}(2)), 7.99$ $\left(3 \mathrm{H}, \mathrm{bs}, \mathrm{NH}_{3}{ }^{+}\right), 8.91(1 \mathrm{H}, \mathrm{bs}, 4-\mathrm{OH}) ;{ }^{13} \mathrm{C}$ NMR $\delta: 17.7 \mathrm{CH}_{3}, 39.5$ $\mathrm{CH}_{2}, 48.2 \mathrm{CH}, 55.5\left(\mathrm{OCH}_{3}\right), 113.2,115.5 \mathrm{C}(2)$ and $\mathrm{C}(5), 121.5$ C (6), 127.3 C (1), 145.4 C (4), 147.6 C (3); EI-MS m/z (\%): 181 $\left(\mathrm{M}^{+\bullet}, 7\right), 138$ (100), 122 (19), 94 (20), 89 (12), 77 (13), 65 (12); mp $245{ }^{\circ} \mathrm{C}$ (dec) (lit (48). mp $244-246{ }^{\circ} \mathrm{C}$ ).

$(R, S)-3,4,5$-Trimethoxyamphetamine Hydrochloride (14). Yield $70 \% ;{ }^{1} \mathrm{H}$ NMR $\delta: 1.09\left(3 \mathrm{H}, d, \mathrm{CH}_{3}\right), 2.64(1 \mathrm{H}, d d, J=13.3 ; 8.4$, $\left.\mathrm{CH}_{2}\right), 2.86\left(1 \mathrm{H}, d d, J=13.3 ; 5.7, \mathrm{CH}_{2}\right), 3.35(1 \mathrm{H}, m, \mathrm{CH}), 3.69$ $\left(3 \mathrm{H}, s, 6-\mathrm{OCH}_{3}\right), 3.77\left(3 \mathrm{H}, s, 3-\mathrm{OCH}_{3}\right), 3.78\left(3 \mathrm{H}, s, 4-\mathrm{OCH}_{3}\right), 6.68$ $(1 \mathrm{H}, s, \mathrm{H}(2)), 6.79(1 \mathrm{H}, s, \mathrm{H}(5)), 7.94\left(3 \mathrm{H}, \mathrm{bs}, \mathrm{NH}_{3}{ }^{+}\right) ;{ }^{13} \mathrm{C} \mathrm{NMR}$ $\delta: 17.8 \mathrm{CH}_{3}, 34.3 \mathrm{CH}_{2}, 47.0 \mathrm{CH}, 55.8,56.1,56.3\left(3 \times \mathrm{OCH}_{3}\right), 98.2$ C (5), 115.3, 115.7 C (1) and C (2), 142.4 C (6), $148.6 \mathrm{C}(3)$, $151.6 \mathrm{C}(4)$; EI-MS m/z (\%): $225\left(\mathrm{M}^{+\bullet}, 11\right), 182$ (100), 167 (32), 151 (15), 139 (8); mp $193-195{ }^{\circ} \mathrm{C}$.

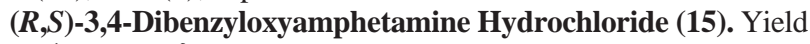
$56 \% ;{ }^{1} \mathrm{H}$ NMR $\delta: 1.08\left(3 \mathrm{H}, d, \mathrm{CH}_{3}\right), 2.59(1 \mathrm{H}, d d, J=13.4 ; 8.8$,
$\left.\mathrm{CH}_{2}\right), 2.93\left(1 \mathrm{H}, d d, J=13.4 ; 5.8, \mathrm{CH}_{2}\right), 3.39(1 \mathrm{H}, m, \mathrm{CH}), 5.13$ $\left(2 \mathrm{H}, s, 3-\mathrm{OCH}_{2}\right), 5.15\left(2 \mathrm{H}, s, 4-\mathrm{OCH}_{2}\right), 6.77(1 \mathrm{H}, d d, J=8.2 ; 1.8$, $\mathrm{H}(6)), 7.00(1 \mathrm{H}, d, J=1.8, \mathrm{H}(2)), 7.20(1 \mathrm{H}, d, J=8.2, \mathrm{H}(5))$, 7.33-7.50 $\left(10 \mathrm{H}, m\right.$, phenyl), $8.07\left(3 \mathrm{H}, \mathrm{bs}, \mathrm{NH}_{3}{ }^{+}\right) ;{ }^{13} \mathrm{C} \mathrm{NMR}: 17.6$ $\mathrm{CH}_{3}, 39.6 \mathrm{CH}_{2}, 48.0 \mathrm{CH}, 70.0\left(2 \times \mathrm{OCH}_{2}\right), 114.5,115.6 \mathrm{C}(2)$ and C (5), 121.9 C (6), 127.6-128.4 (10×CHAr), $129.6 \mathrm{C}(1), 137.3$, 137.4 (2×CAr), 147.1 C (3), $148.1 \mathrm{C}$ (4); EI-MS m/z (\%): 348 $\left(\mathrm{M}^{+\bullet}, 5\right), 181$ (12), 91 (100), 65 (14); mp 130-132 ${ }^{\circ} \mathrm{C}$ (lit (45). mp $130-133{ }^{\circ} \mathrm{C}$ ).

General Synthetic Procedure for the N-Methylation of the Amphetamine Derivatives. Compounds 16, 17, and 18 were synthesized according to a synthetic route published earlier (47). The preparation of these secondary amines, starting from the respective primary amines, was preformed by a two-step reaction pathway, in which the intermediate was a carbamate derivative. The amine hydrochlorides (11, 12, and 15) (4.5 mmol) were dissolved in water $(30 \mathrm{~mL})$ at $0{ }^{\circ} \mathrm{C}$. A solution of $\mathrm{NaOH}(0.3 \mathrm{~g})$ in water $(2.5 \mathrm{~mL})$ was then added to the reaction followed by the addition of ethylchloroformate $(0.5 \mathrm{~mL}, 5.3 \mathrm{mmol})$. The suspension was stirred at $0{ }^{\circ} \mathrm{C}$ for $3 \mathrm{~h}$, and the reaction was then stopped by extraction with $3 \times 100 \mathrm{~mL}$ of dichloromethane. The organic layer was dried, and the solvent was evaporated to obtain the corresponding urethane (R-NHCOOEt) (yields around 85\%). These compounds were then reduced to the methylated amine by reaction with $\mathrm{LiAlH}_{4}$. Briefly, the carbamates $(4.1 \mathrm{mmol})$ were dissolved in THF $(15 \mathrm{~mL})$, and this solution was slowly added to lithium aluminum hydride $(12 \mathrm{mmol})$ suspended in THF $(25 \mathrm{~mL})$, under $\mathrm{N}_{2}$. The reaction was stirred and heated under reflux for $10 \mathrm{~h}$. The quenching of the reaction, purification procedure, and the salification were performed by the same technique used in the previous reaction step. The purified compounds were fully characterized with the following structural features.

(R,S)-3,4-Dimethoxymethamphetamine Hydrochloride (17). Yield 55\%; ${ }^{1} \mathrm{H}$ NMR $\delta$ : $1.09\left(3 \mathrm{H}, d, \mathrm{CH}_{3}\right), 2.54\left(3 \mathrm{H}, s, \mathrm{NCH}_{3}\right)$, $2.56\left(1 \mathrm{H}, d d, J=13.2 ; 8.2, \mathrm{CH}_{2}\right), 3.07(1 \mathrm{H}, d d, J=13.2 ; 4.5$, $\left.\mathrm{CH}_{2}\right), 3.35(1 \mathrm{H}, m, \mathrm{CH}), 3.72\left(3 \mathrm{H}, s, 3-\mathrm{OCH}_{3}\right), 3.75(3 \mathrm{H}, s$, $\left.4-\mathrm{OCH}_{3}\right), 6.74(1 \mathrm{H}, d d, J=8.2 ; 1.8, \mathrm{H}(6)), 6.86(1 \mathrm{H}, d, J=$ $1.8, \mathrm{H}(2)), 6.90(1 \mathrm{H}, d, J=8.2, \mathrm{H}(5)), 8.90\left(2 \mathrm{H}, \mathrm{bs}, \mathrm{NH}_{2}{ }^{+}\right)$; ${ }^{13} \mathrm{C}$ NMR $\delta: 15.0 \mathrm{CH}_{3}, 29.6 \mathrm{NCH}_{3}, 37.9 \mathrm{CH}_{2}, 55.3 \mathrm{CH}$, $55.4\left(2 \times \mathrm{OCH}_{3}\right), 111.8,112.9 \mathrm{C}(2)$ and $\mathrm{C}(5), 121.3 \mathrm{C}(6), 128.8$ C (1), 147.7 C (3), 148.7 C (4); EI-MS m/z (\%): $210\left(\mathrm{M}^{+\bullet}, 6\right)$, 152 (16), 107 (5), 72 (7), 58 (100); mp $118-120{ }^{\circ} \mathrm{C}$ (lit (43). mp $\left.117-119^{\circ} \mathrm{C}\right)$.

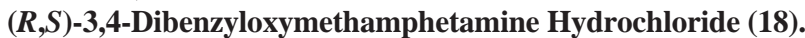
Yield 42\%; ${ }^{1} \mathrm{H}$ NMR $\delta: 1.04\left(3 \mathrm{H}, d, \mathrm{CH}_{3}\right), 2.53\left(3 \mathrm{H}, s, \mathrm{NCH}_{3}\right)$, $2.55\left(1 \mathrm{H}, d d, J=13.2 ; 8.4, \mathrm{CH}_{2}\right), 3.03(1 \mathrm{H}, d d, J=13.2 ; 4.3$, $\left.\mathrm{CH}_{2}\right), 3.35(1 \mathrm{H}, m, \mathrm{CH}), 5.10\left(2 \mathrm{H}, s, 3-\mathrm{OCH}_{2}\right), 5.12(2 \mathrm{H}, s$, $\left.4-\mathrm{OCH}_{2}\right), 6.75(1 \mathrm{H}, d d, J=8.2 ; 1.9, \mathrm{H}(6)), 6.99(1 \mathrm{H}, d, J=2.0$, $\mathrm{H}(2)), 7.01(1 \mathrm{H}, d, J=8.2, \mathrm{H}(5)), 7.29-7.46(10 \mathrm{H}, m$, phenyl), $8.74\left(2 \mathrm{H}, \mathrm{bs}, \mathrm{NH}_{2}{ }^{+}\right) ;{ }^{13} \mathrm{C} \mathrm{NMR} \delta: 15.0 \mathrm{CH}_{3}, 29.7 \mathrm{NCH}_{3}, 37.9$ $\mathrm{CH}_{2}, 55.3 \mathrm{CH}, 70.1\left(2 \times \mathrm{OCH}_{2}\right), 114.5,115.7 \mathrm{C}(2)$ and $\mathrm{C}(5), 121.9$

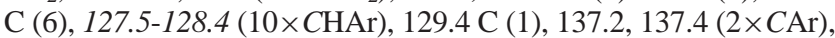
$147.2 \mathrm{C}(3), 148.1 \mathrm{C}(4)$; EI-MS m/z (\%): $361\left(\mathrm{M}^{+\bullet}, 5\right), 304$ (22), 181 (4), 91 (46), 65 (7), 58 (100); mp $152-155^{\circ} \mathrm{C}$.

General Synthetic Procedure for the O-Demethylation. The process of $O$-demethylation to obtain the phenolic derivatives (19-21) was based on a method described earlier $(47,49)$. The first step was the transformation of the hydrochloride salts in the respective free base amines, by dissolving them in water, making them alkaline with $\mathrm{NH}_{3}$ solution, and extracting with dichloromethane. The di or trihydroxilated compounds 12,14 , and 17 (4.5 mmol) were then dissolved in anhydrous dichloromethane (50 $\mathrm{mL})$ in an inert atmosphere $\left(\mathrm{N}_{2}\right)$ and at $-60{ }^{\circ} \mathrm{C}$. To this solution, boron tribromide $(13 \mathrm{~mL}$ of $1 \mathrm{M}$ solution in dichloromethane, 13 mmol) was added, and the reaction was kept at $-60{ }^{\circ} \mathrm{C}$ for 10 min and then allowed to reach room temperature for $4 \mathrm{~h}$. The reaction was quenched by cautious addition of methanol $(10 \mathrm{~mL})$, and the solvent evaporated yielding a residue of the hydrobromide salt. Compound 19 was obtained as an almost white solid after recrystallization with acetonitrile. Compound $\mathbf{2 0}$ was recrystallized from dichloromethane as a white solid that quickly turns into a 
dark oil at room temperature and when exposed to air. The data obtained was in accordance with that described in the literature $(10-13)$.

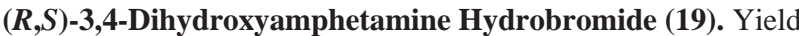
$57 \% ;{ }^{1} \mathrm{H}$ NMR $\delta: 1.08\left(3 \mathrm{H}, d, \mathrm{CH}_{3}\right), 2.46(1 \mathrm{H}, d d, J=13.4 ; 8.8$, $\left.\mathrm{CH}_{2}\right), 2.77\left(1 \mathrm{H}, d d, J=13.4 ; 5.4, \mathrm{CH}_{2}\right), 3.30(1 \mathrm{H}, m, \mathrm{CH}), 6.46$ $(1 \mathrm{H}, d d, J=8.0 ; 1.9, \mathrm{H}(6)), 6.59(1 \mathrm{H}, d, J=1.9, \mathrm{H}(2)), 6.68$ $(1 \mathrm{H}, d, J=8.0, \mathrm{H}(5)), 7.78\left(3 \mathrm{H}, \mathrm{bs}, \mathrm{NH}_{3}{ }^{+}\right), 8.85(2 \mathrm{H}, \mathrm{bs}, 2 \times \mathrm{OH})$; ${ }^{13} \mathrm{C}$ NMR $\delta: 17.6 \mathrm{CH}_{3}, 39.6 \mathrm{CH}_{2}, 48.3 \mathrm{CH}, 115.7,116.5 \mathrm{C}(2)$ and C (5), 119.9 C (6), 127.2 C (1), $144.2 \mathrm{C}(3), 145.2 \mathrm{C}(4)$; EI-MS m/z (\%):168 (M+• 8), 151 (12), 124 (42), 123 (70), 107 (8), 84 (62), 80 (62), 79 (21), 77 (97), 66 (100); mp 189-192 ${ }^{\circ} \mathrm{C}$ (lit (10). mp $193-195^{\circ} \mathrm{C}$ ).

$(R, S)$-2,4,5-Trihydroxyamphetamine Hydrobromide (20). Yield $65 \% ;{ }^{1} \mathrm{H}$ NMR $\delta: 1.06\left(3 \mathrm{H}, d, \mathrm{CH}_{3}\right), 2.50(1 \mathrm{H}, d d, J=13.3 ; 8.6$, $\left.\mathrm{CH}_{2}\right), 2.70\left(1 \mathrm{H}, d d, J=13.3 ; 5.5, \mathrm{CH}_{2}\right), 3.38(1 \mathrm{H}, m, \mathrm{CH}), 6.34$ $(1 \mathrm{H}, s, \mathrm{H}(2)), 6.44(1 \mathrm{H}, s, \mathrm{H}(5)), 7.74\left(3 \mathrm{H}, \mathrm{b} s, \mathrm{NH}_{3}{ }^{+}\right), 8.80(3 \mathrm{H}$, bs, $3 \times \mathrm{OH}) ;{ }^{13} \mathrm{C}$ NMR $\delta: 17.8 \mathrm{CH}_{3}, 34.7 \mathrm{CH}_{2}, 47.3 \mathrm{CH}, 103.7 \mathrm{C}$ (5), 112.3 C (1), 117.9 C (2), 137.6 C (6), $144.6 \mathrm{C}(3), 147.9 \mathrm{C}$ (4); EI-MS m/z (\%): $183\left(\mathrm{M}^{+\bullet}, 4\right), 163$ (14), 140 (5), 84 (77), 66 (100)

General Synthetic Procedure for the O-Debenzylation. The synthesis was carried out by catalytic hydrogenolysis of compounds 15 and 18 as described earlier (46). In a flask containing Argon and $10 \% \mathrm{Pd} / \mathrm{C}(300 \mathrm{mg}$ ) previously wetted with dry methanol, a solution of 15 and $18(2.5 \mathrm{mmol})$ in methanol $(30 \mathrm{~mL})$ was added. The mixture was then hydrogenated catalytically in a PARR pump, at room temperature and at 40 psi until no more hydrogen was consumed, and the reaction ended (approximately $2 \mathrm{~h}$ ). The suspension was filtered by suction to eliminate $\mathrm{Pd} / \mathrm{C}$, and methanol was partially evaporated, $\mathrm{HCl}$ was added to form the hydrochloride salt of the catecholic compounds. Acetonitrile was used as the recrystallization solvent and compound $\mathbf{2 1}$ was obtained as a light brownish oil and used directly.

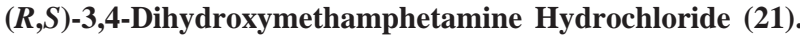
Yield 72\%; ${ }^{1} \mathrm{H}$ NMR $\delta: 1.06\left(3 \mathrm{H}, d, \mathrm{CH}_{3}\right), 2.49\left(3 \mathrm{H}, s, \mathrm{NCH}_{3}\right)$, $2.53\left(1 \mathrm{H}, d d, J=13.2 ; 8.3, \mathrm{CH}_{2}\right), 2.98(1 \mathrm{H}, d d, J=13.2 ; 4.2$, $\left.\mathrm{CH}_{2}\right), 3.33(1 \mathrm{H}, m, \mathrm{CH}), 6.45(1 \mathrm{H}, d d, J=8.0 ; 1.9, \mathrm{H}(6)), 6.60$ $(1 \mathrm{H}, d, J=1.9, \mathrm{H}(2)), 6.67(1 \mathrm{H}, d, J=8.0, \mathrm{H}(5)), 8.03(2 \mathrm{H}, \mathrm{b} s$, $2 \times \mathrm{OH}), 8.92\left(2 \mathrm{H}, \mathrm{bs}, \mathrm{NH}_{2}{ }^{+}\right) ;{ }^{13} \mathrm{C} \mathrm{NMR} \delta: 14.9 \mathrm{CH}_{3}, 29.6 \mathrm{NCH}_{3}$, $37.8 \mathrm{CH}_{2}, 55.6 \mathrm{CH}, 115.8,116.7 \mathrm{C}(2)$ and $\mathrm{C}(5), 120.0 \mathrm{C}(6)$, 127.3 C (1), $144.1 \mathrm{C}(3), 145.3 \mathrm{C}(4)$; EI-MS m/z (\%): $180\left(\mathrm{M}^{+\bullet}\right.$, 8), 166 (13), 151 (6), 123 (57), 105 (12), 91 (11), 86 (100), 77 (53), 66 (24).

Biological Methods. Culture of Undifferentiated PC12 Cells. PC12 cells, derived from a pheochromocytoma of the rat adrenal medulla, were cultured in RPMI 1640 medium (with 1-glutamine and HEPES) supplemented with 10\% (v/v) horse serum, 5\% (v/v) fetal bovine serum (FBS), $50 \mathrm{U} / \mathrm{mL}$ penicillin, and $50 \mathrm{mg} / \mathrm{mL}$ streptomycin (final $\mathrm{pH}$ at about 7.4), as described before (50).

Cultures were preserved in $75 \mathrm{~cm}^{2}$ flasks at $37^{\circ} \mathrm{C}$ in a humidified incubator containing $95 \%$ air and $5 \% \mathrm{CO}_{2}$, and passed at least twice a week. The cells were plated on poly-L-lysine-coated multiwells at a density of 100000 cells $/ \mathrm{cm}^{2}$ for MTT assays. In what is related with the study of chromatin condensation, the cells were plated in coverslips pre-coated with poly-L-lysine at a density of 180000 cells $/ \mathrm{cm}^{2}$. The cells were additionally incubated with MDMA and its metabolites (placed as aqueous solutions) for more $24 \mathrm{~h}$.

Analysis of Cell Viability. Cell viability was measured by the 3-(4,5-dimethylthiazol-2-yl)-2,5-diphenyltetrazolium bromide (MTT) reduction assay (51). Following the incubation of the cells for 24 $\mathrm{h}$ with the tested compounds, they were washed with sodium solution (in mM: $140 \mathrm{NaCl}, 5 \mathrm{KCl}, 1 \mathrm{MgCl}_{2}, 1 \mathrm{NaH}_{2} \mathrm{PO}_{4}, 1.5 \mathrm{CaCl}_{2}$, 5.6 glucose, and 20 HEPES (pH 7.4)) and incubated further with $0.2 \mathrm{~mL}$ of MTT solution $(0.5 \mathrm{mg} / \mathrm{mL}$ dissolved in sodium solution containing $1.0 \mathrm{mM}$ of $\mathrm{CaCl}_{2}$ ) for $2.5 \mathrm{~h}$. The blue formazan precipitate, produced after the reduction of MTT by cellular dehydrogenases, was resuspended and dissolved after addition of $0.2 \mathrm{~mL}$ of acidic isopropanol $(0.04 \mathrm{M}$ of $\mathrm{HCl})$. The capacity of treated cells in reducing the tetrazolium salt was expressed as a percentage of absorbance in control cells (ELISA microplate reader at $570 \mathrm{~nm}$ ).

Analysis of Chromatin Condensation. The fluorescent probes SYTO-13 and PI (propidium iodide) were used to evaluate the morphological evidence of cell death by necrosis and/or apoptosis, after preincubation of the cells with the compounds in a concentration close to $\mathrm{IC}_{50}$.

Necrosis and apoptosis were evaluated concomitantly on cultured PC12 cells after double fluorescence staining using vital fluorescence dyes SYTO-13 (a permeant intercalating probe that labels RNA and DNA in living cells with an UV-excited green-colored emission) and propidium iodide (a nonpermeant intercalating probe, which is excluded from viable cells with an UV-excited red emission). Normal nuclei exhibited loose chromatin colored green by SYTO-13; apoptotic nuclei exhibited condensed green-colored chromatin (postapoptotic necrosis or secondary apoptosis (52) was characterized by nuclei exhibiting the same apoptotic morphological features, but with red colored chromatin); necrotic cells exhibited red-colored nuclei with loose chromatin.

The cells were loaded for $3 \mathrm{~min}$ with sodium solution containing SYTO-13 $(4 \mu \mathrm{M})$ and PI $(4 \mu \mathrm{g} / \mathrm{mL})$. The cells were then visualized and counted by fluorescence microscopy in a Nikon diaphot microscope equipped with a Xenon lamp and a FX 64 Omega Optical triple filter. Apoptotic and necrotic cells were scored by counting at least 200 nuclei in four or more random different fields in triplicates from three different experiments.

Statistical Analysis. Data presented are the mean \pm SEM from the number of experiments indicated in the Figure legends, performed in triplicate. For the comparison of MTT reduction between treated cells and controls, we performed one-way statistical analysis of variance (ANOVA) followed by the Tukey-Kramer post-hoc test. For the analysis of chromatin condensation, statistical analysis was performed by the Kruskal-Wallis test followed by the Mann-Whitney multiple comparison with Bonferroni correction. In both cases, significance was accepted at $p<0.05$.

\section{Results and Discussion}

Chemistry. MDMA and its major metabolites are ringsubstituted phenethylamine derivatives structurally related to psychomotor stimulant amphetamines and the hallucinogen mescaline.

The total synthesis of the drug and its main metabolites was based on the general pathway presented in Figure 2.

Briefly, the synthesis of the target compounds was performed in a straightforward manner, starting from the appropriate substituted benzaldehydes $(\mathbf{1}-\mathbf{5})$, which were converted into the corresponding phenylisopropylamines $(\mathbf{1 1}-\mathbf{1 5})$ via $\beta$-methyl- $\beta$-nitrostyrenes $(\mathbf{6}-\mathbf{1 0})$ intermediates. First, a Knoevenagel condensation between the aldehyde, with the corresponding aromatic substitution pattern, and nitroethane was carried out, yielding the nitrostyrene derivatives (53). These compounds were then reduced to the unsaturated primary amines by lithium aluminum hydride $\left(\mathrm{LiAlH}_{4}\right)$. When necessary, the subsequent $\mathrm{N}$-methylation of the amphetamine derivatives 11, 12, and $\mathbf{1 5}$ was accomplished by a two-step reaction path, beginning with the treatment with ethylchloroformate to provide the $\mathrm{N}$-formyl derivatives followed by a reduction with $\mathrm{LiAlH}_{4}$ to yield the designed $N$-methylated products $(\mathbf{1 6}-\mathbf{1 8})$. Finally and in order to obtain the phenolic amphetamine analogous (19-21), compounds 12,14 , and 17 were $O$-demethylated after reaction with boron tribromide $\left(\mathrm{BBr}_{3}\right)$.

Prior to the characterization procedures and biological assays, all of the compounds containing an amine group were converted to their hydrochloride or hydrobromide salts, according to the employed synthetic route and/or stability of the final compound.

Derivative 13 (4-hydroxy-3-methoxyamphetamine), as a hydrochloride, was also prepared in fairly good yield by 


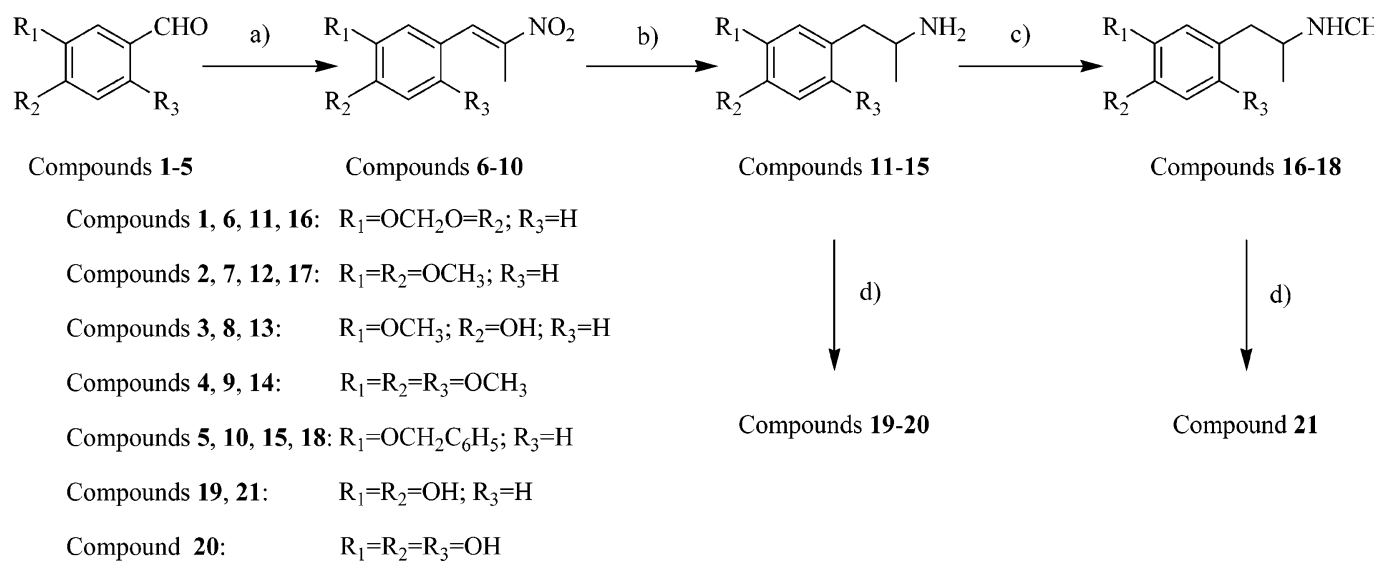

Figure 2. General synthetic procedure for MDMA and its metabolites. Chemical conditions: (a) $\mathrm{EtNO}_{2}, \mathrm{NH}_{4} \mathrm{CH}_{3} \mathrm{COO}, \mathrm{reflux}$; (b) $\mathrm{LiAlH}_{4}, \mathrm{THF}$, reflux; (c) $1 . \mathrm{ClCOOC}_{2} \mathrm{H}_{5}, \mathrm{H}_{2} \mathrm{O}, \mathrm{NaOH}, 0{ }^{\circ} \mathrm{C} ; 2 . \mathrm{LiAlH}_{4}$, THF, reflux; (d) for the methylated compounds $(\mathbf{1 2}, \mathbf{1 4}, \mathbf{1 7}): \mathrm{BBr}_{3}, \mathrm{CH}_{2} \mathrm{Cl}_{2},-60{ }^{\circ} \mathrm{C}$; for the benzylated compounds $(\mathbf{1 5}, \mathbf{1 8}): \mathrm{H}_{2}, \mathrm{Pd} / \mathrm{C}, \mathrm{MeOH}$. See Experimental Procedures.

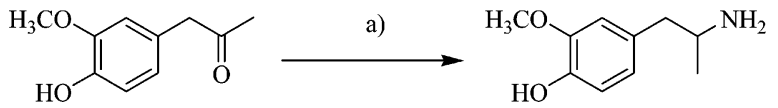

Figure 3. Reductive amination route for the synthesis of 3-OMe- $\alpha$-MeDA (13). Chemical conditions: (a) ammonium acetate $\left(\mathrm{NH}_{4} \mathrm{CH}_{3} \mathrm{COO}\right)$ and sodium cyanoborohydride $\left(\mathrm{NaCNBH}_{3}\right)$ in methanol $\left(24 \mathrm{~h} / \mathrm{rt} / \mathrm{N}_{2} / \mathrm{pH} 6\right)$.

reductive amination of the ketone 4-hydroxy-3-methoxyphenylacetone (Figure 3) (10).

The synthetic approach leading to the phenolic compounds 19-21 requires protection/deprotection steps to prevent alleged side reactions. Because the process of deprotection and following purification seems to be a limitative key step of the designed synthetic procedure, it was interesting to study different strategies to synthesize compounds $\mathbf{1 9}$ and $\mathbf{2 1}$ with the main goal of improving the overall yield. For the protection of the catechol of the starting material (3,4-dihydroxybenzaldehyde), the following protecting groups were used: benzyl (Bn or $-\mathrm{CH}_{2} \mathrm{C}_{6} \mathrm{H}_{5}$ ), methoxymethyl (MOM), tetrahydropyranyl (THP), and di-tertbutyldichlorosilyl (DTBS) ethers (54). The yields of these protection reactions were not significantly different, except for benzylic ether, which seems to be a good alternative because the benzylated benzaldehyde was obtained in good yield, and the deprotected final amines ( $\alpha$-MeDA and $N$-Me- $\alpha-M e D A)$ can be easily achieved by hydrogenolysis (a selective, apparently smoother and cleaner reaction compared to that of boron tribromide demethylation; see Experimental Procedures) (Figure 4).

All of the synthesized compounds were identified by both NMR and electron impact mass spectroscopy (EI-MS), and their purity was confirmed using the HPLC systems reported in Experimental Procedures.

Biological Assays: Analysis of Cell Viability. The putative neurotoxic effects of this series of compounds were evaluated by two different types of assays: (i) analysis of PC12 cell viability after incubation with increasing concentrations of the tested compounds and (ii) analysis of chromatin fragmentation/ condensation after incubation of PC12 cells with a concentration close to the respective $\mathrm{IC}_{50}$ values (concentration of the drug that decreases cell viability by $50 \%$ ). The cell line selected for the cytotoxicity studies is derived from a catecholaminesecreting tumor (pheochromocytoma) of rat adrenal medulla, which upon exposure to nerve growth factor (NGF) differentiates into a neuronal phenotype similar to that of the postganglionic sympathetic (catecholaminergic) nerve-like cell (34). Undifferentiated PC12 cells are commonly used for the screening of cytotoxicity and to study the disruption by neurotoxicants related to various aspects of neuronal physiology and biochemistry (55, 56). It is worthwhile to mention that undifferentiated PC12 cells release more dopamine and less acetylcholine than differentiated cells (34).

Studies of cell toxicity were performed by analyzing cellreducing capacity through the examination of the ability of these cells to reduce MTT (3-(4,5-dimethylthiazol-2-il)-2,5-diphenyltetrazolium). The MTT measures the reducing capacity of the cells, a parameter dependent upon the maintenance of cellular metabolic function, thus reflecting cell viability and/or proliferation. This tetrazolium salt (yellow and soluble) is reduced to formazan (blue and insoluble) by active cellular dehydrogenases. The number of metabolically viable cells in the culture was directly correlated with the amount of formazan dye formed.

Changes in cell viability caused by exposure to MDMA or its five metabolites were evaluated and compared as shown in Figure 5. All of the compounds induced a dose-dependent decrease in cell viability after $24 \mathrm{~h}$ of incubation; however, the catechol-containing metabolites (19-21) were considerably more toxic to $\mathrm{PC} 12$ cells because their $\mathrm{IC}_{50}$ values are significantly lower than the ones of MDA and MDMA, as determined by the analysis of all of the $\mathrm{IC}_{50}$ values: $\mathrm{IC}_{50} \sim 158 \mu \mathrm{M}(\mathrm{N}$ $\mathrm{Me}-\alpha-\mathrm{MeDA})<\mathrm{IC}_{50} \sim 247 \mu \mathrm{M}(6-\mathrm{OH}-\alpha-\mathrm{MeDA})<\mathrm{IC}_{50} \sim 416$ $\mu \mathrm{M}(\alpha-\mathrm{MeDA}) \ll \mathrm{IC}_{50} \sim 3365 \mu \mathrm{M}(\mathrm{MDA})<\mathrm{IC}_{50} \sim 4464 \mu \mathrm{M}$ (MDMA) $<\mathrm{IC}_{50} \sim 7526 \mu \mathrm{M}(3-O-\mathrm{Me}-\alpha-\mathrm{MeDA})$, decreasing order of toxicity. The range of concentrations achieved is believed to occur in vivo after repeated drug usage (57).

Evaluation of Necrosis and Apoptosis. Apoptosis has been shown to play a key role in the cytotoxic effects of many drugs, including amphetamine derivatives $(36,37)$. However, the precise role of apoptosis in the toxic effects of MDMA and its metabolites in dopaminergic cells has not been fully accomplished. Thus, upon analysis of cell viability, we attempted to characterize cell death as apoptotic and/or necrotic, by studying the morphological changes of the nuclei.

We analyzed the fragmentation/condensation of chromatin, a characteristic feature of apoptosis, by using the SYTO-13/PI assay. Apoptotic cells resulted in shrunken, brightly green fluorescent nuclei due to SYTO-13 labeling, showing condensed chromatin with high fluorescence compared with nonapoptotic cells. Simultaneous labeling with propidium iodide (PI), a nonpermeable fluorescent dye, excluded from the living cells, allowed the detection of nucleic acids in intact nuclei of membrane-damaged cells (red fluorescence), characteristic of necrotic cell death. Late or secondary apoptosis was characterized by SYTO-13 plus PI labeling of fragmented/condensed nuclei. 


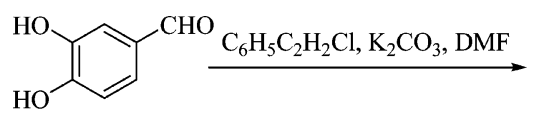<smiles>O=Cc1ccc(OC(Br)(Br)c2ccccc2)c(OCc2ccccc2)c1</smiles><smiles>CCOCCCCCC(N)=O</smiles><smiles>C/C(=C\c1ccc(OCc2ccccc2)c(OCc2ccccc2)c1)[N+](=O)[O-]</smiles><smiles>CC(N)Cc1ccc(O)c(O)c1</smiles>

(19)

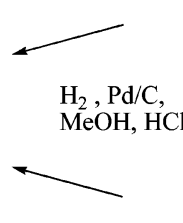

$\mathrm{LiAlH}_{4}$, THF
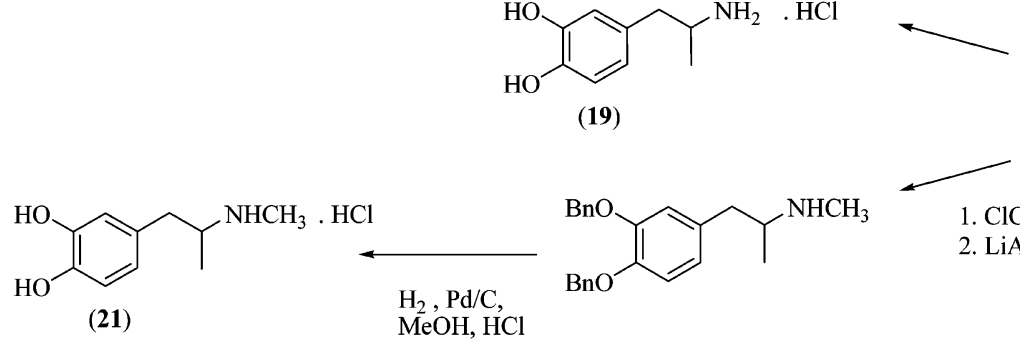

1. $\mathrm{ClCOOC}_{2} \mathrm{H}_{5}, \mathrm{H}_{2} \mathrm{O}, \mathrm{NaOH}$

2. $\mathrm{LiAlH}_{4}, \mathrm{THF}$

(21)

$\mathrm{H}_{2}, \mathrm{Pd} / \mathrm{C}$,
$\mathrm{MeOH}, \mathrm{HC}$

Figure 4. Proposed synthetic strategies for the total synthesis of $\alpha$-MeDA (19) and $N$-Me- $\alpha$-MeDA (21) using a benzyl group to protect the catechol.

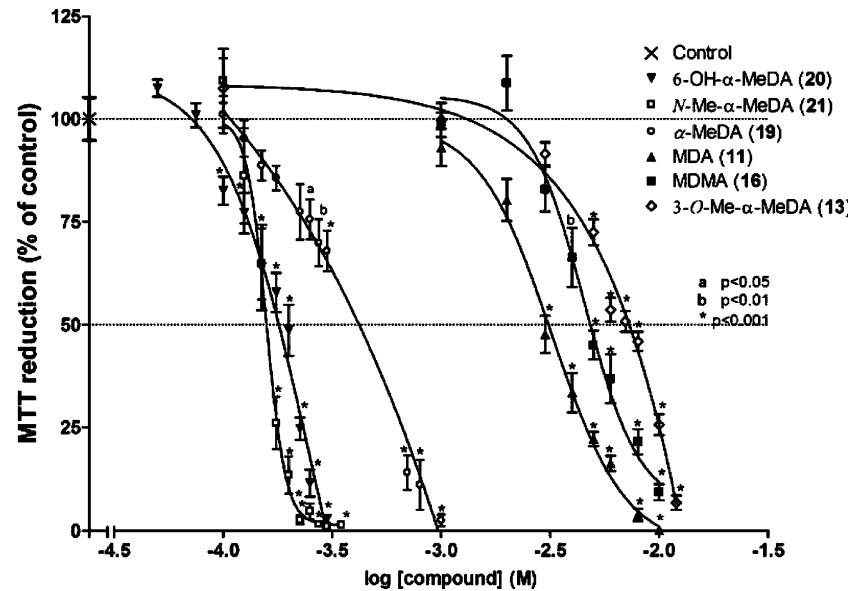

Figure 5. Dose-response curves of MDMA and metabolite-induced cytotoxicity. PC12 cells were incubated with increasing concentrations of the compounds for $24 \mathrm{~h}$, and the toxic effects were evaluated by the MTT reduction assay (percentage of MTT reduction relative to the control). Data are the mean \pm SEM of at least three experiments performed in triplicate.

To determine the fraction of fragmented/condensed nuclei, PC12 cells were incubated with the compounds for $24 \mathrm{~h}$ in concentrations in the vicinity of the $\mathrm{IC}_{50}$ values as determined in Figure 5. Under these conditions, there was a decrease by 15 to $30 \%$ in the number of viable cells (Figure 6). It should be noted that the loss of cell-reducing capacity (ascertained by the MTT assay) may not correspond immediately to cell death, as evidenced by the SYTO13/PI assay. Cells may have lost metabolic activity before showing evidence of a loss of membrane integrity or nuclear fragmentation or condensation.

All of the compounds tested, with the exception of $\alpha-M e D A$, induced fragmentation and condensation of chromatin and, therefore, apoptosis when compared to the control, as observed by the labeling with SYTO-13 (Figure 6). MDMA, MDA, $N$-Me- $\alpha$-MeDA, and $\alpha$-MeDA revealed an increase of necrotic cell death compared to the control.

By comparing the relative proportion of the cells showing features of necrosis and apoptosis for each compound, it is important to highlight that although in a relatively small percentage $N$-Me- $\alpha$-MeDA causes cell death mainly by apoptosis (by 6\%), MDMA (by $8 \%$ ) and $\alpha-M e D A$ (by $13.7 \%$ ) cause cell death mostly by necrosis, whereas the other compounds did not induce a predominant type of cell death.

Comparison of features of apoptosis and necrosis observed for MDMA and its metabolites revealed no significant differ-

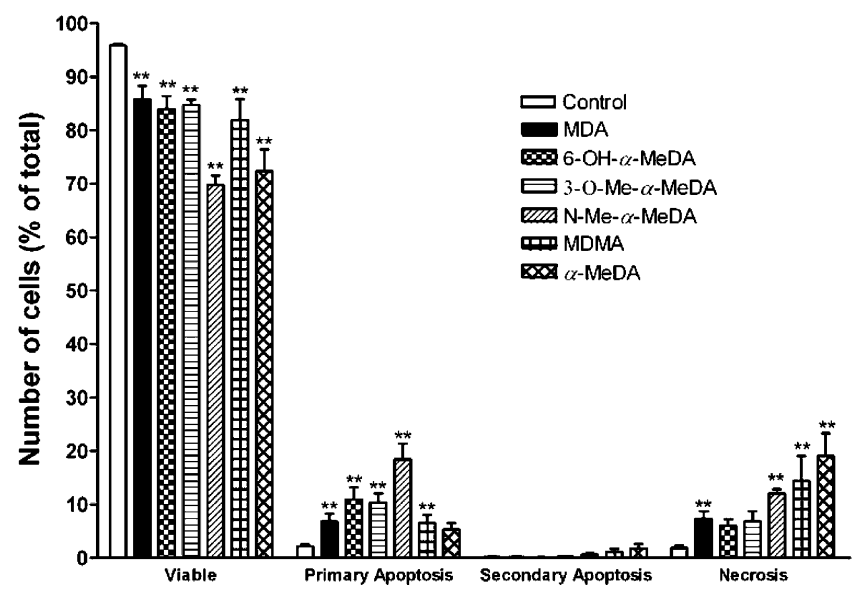

Figure 6. Analysis of chromatin condensation in PC12 cells exposed to the six compounds: $N$-Me- $\alpha-\mathrm{MeDA}, 6-\mathrm{OH}-\alpha-\mathrm{MeDA}, \alpha-\mathrm{MeDA}(300$ $\mu \mathrm{M}$ each), MDA, MDMA, and 3-O-Me- $\alpha-\mathrm{MeDA}$ (3 $\mathrm{mM}$ each) incubated for $24 \mathrm{~h}$. SYTO-13 and propidium iodide (PI) were used to evaluate apoptotic or necrotic cell death. Data are the mean \pm SEM of three experiments performed in triplicate. Statistical significance compared to the control (in the absence of the drug): $*^{*} p<0.01$ with Bonferroni correction is considered very significant.

ences between the groups and, therefore, no major changes in the profile of cell death evoked by all of the compounds tested.

Structure-Oxidation-Toxicity Relationships. Because cytotoxic effects are frequently ascribed to be related to the occurrence of redox reactions, standard redox potentials of MDMA and its metabolites were determined in order to establish the relationship between the observed cytotoxicity and the oxidative profile. The electrochemical behavior of the compounds was studied at physiological $\mathrm{pH} 7.3$, at a glassy carbon working electrode (GCE) using differential pulse, cyclic, and square wave voltammetry.

From the analysis of the electrochemical data of the drug and metabolites, it was possible to clearly distinguish two sets of compounds (Figure 7): one containing the metabolites with a catecholic group ( $\alpha$-MeDA (19), 6-OH- $\alpha$-MeDA (20), $N$-Me$\alpha-\operatorname{MeDA}(\mathbf{2 1}))$ and the other including the compounds with a substituted catechol function (MDA (11), 3-O-Me- $\alpha-M e D A$ (13), MDMA (16)).

For 6-OH- $\alpha-\operatorname{MeDA}(\mathbf{2 0}), N-\mathrm{Me}-\alpha-\operatorname{MeDA}(\mathbf{2 1})$, and $\alpha-\mathrm{MeDA}$ (19), two well-defined anodic peaks were observed at physiological $\mathrm{pH}$ using differential pulse voltammetry (Figure 7a). The first peak is related to the oxidation of the catechol group to $o$-quinone and occurs at $E_{\mathrm{p}}=-0.11 \mathrm{~V}$ for compound 20 


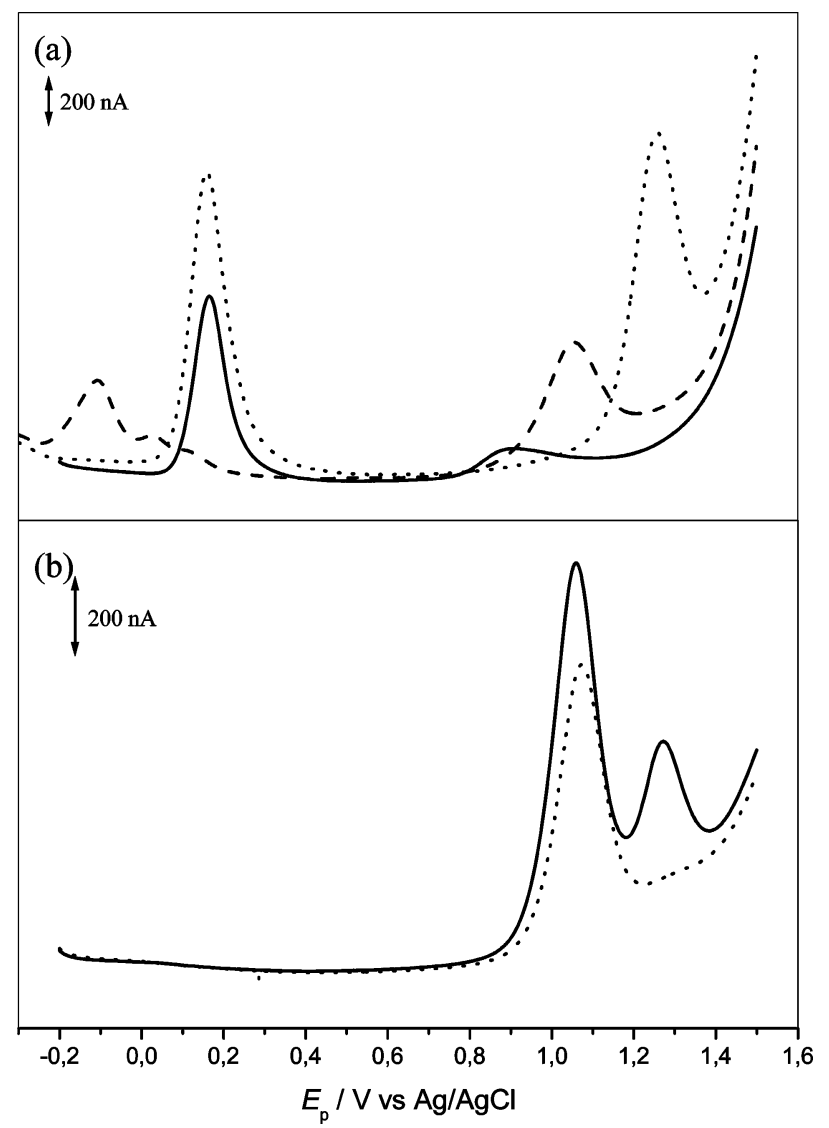

Figure 7. Differential pulse voltammograms in $\mathrm{pH} 7.3$ phosphate supporting electrolyte of $0.1 \mathrm{mM}$ solutions of (a) (---) 6-OH- $\alpha-\mathrm{MeDA}$, $(\cdots \cdots) N$-Me- $\alpha$-MeDA and (-) $\alpha-M e D A ;(b)(-)$ MDMA and (…) MDA. Scan rate $5 \mathrm{mVs}^{-1}$.

and $+0.16 \mathrm{~V}$ for compounds $\mathbf{1 9}$ and 21. Cyclic and square wave voltammograms recorded for these compounds clearly show the reversible character of this first electron-transfer oxidation reaction, which is consistent with the formation of quinonoid structures. The second anodic wave occurring at more positive potentials (Figure 7a) could be due to the oxidation of the quinone side-chain. MDMA (16) presents two well-defined anodic peaks at physiological $\mathrm{pH}$ using differential pulse voltammetry (Figure $7 \mathrm{~b}$ ). The first, $E_{\mathrm{p}}=+1.06 \mathrm{~V}$, is due to the removal of one electron from the aromatic ring with the formation of a radical cation stabilized by the substituents, and the second peak, $E_{\mathrm{p}}=+1.27 \mathrm{~V}$, could be attributed to the oxidation of the secondary amine present in the structure. MDA (11) showed only a single and well-defined anodic wave at physiological $\mathrm{pH}, E_{\mathrm{p}}=+1.07 \mathrm{~V}$ (Figure $7 \mathrm{~b}$ ) attributed also to the removal of one electron from the aromatic ring, the same oxidation process as in MDMA. For 3-O-Me- $\alpha-M e D A$ (13), a well-defined anodic peak is observed at physiological $\mathrm{pH}$ using differential pulse voltammetry (Figure 8 ). This peak, $E_{\mathrm{p}}=+0.43$ $\mathrm{V}$, is due to the oxidation of the phenolic group. An indistinct second wave also appears at ca. $+1.15 \mathrm{~V}$ (Figure 8), which might correspond to the formation of the radical aromatic cation.

Regarding the redox potentials obtained for the compounds, which are summarized in Table 1, it is possible to depict a clear correlation: all of the catechol-containing metabolites are more easily oxidized and remarkably more cytotoxic (Figure 5), a feature that could be intrinsically related with the in situ formation of electrophilic quinones. In fact, the obtained electrochemical data allow us to show that the catecholic metabolites share a common oxidative profile with the formation of quinones as primary oxidation products, which are highly

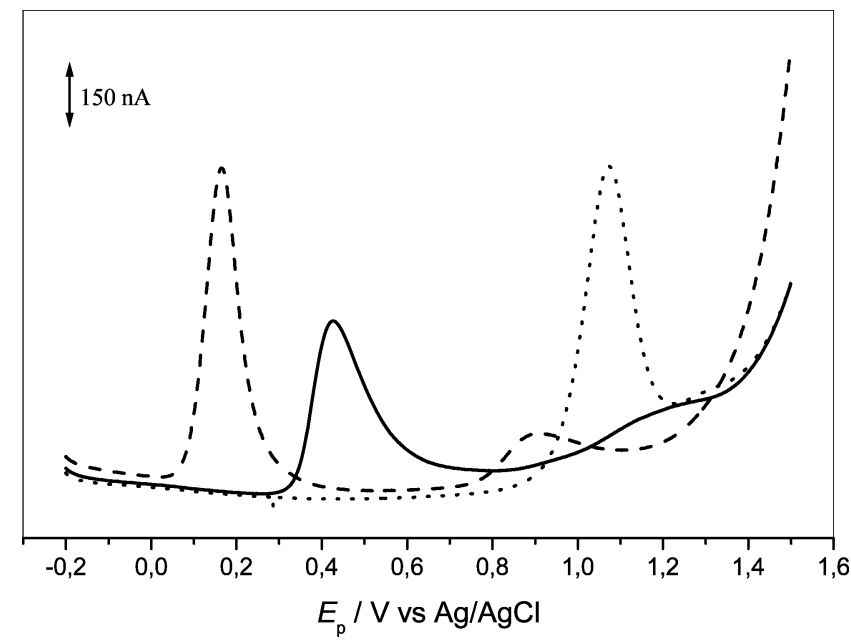

Figure 8. Differential pulse voltammograms in $\mathrm{pH} 7.3$ phosphate supporting electrolyte of $0.1 \mathrm{mM}$ solutions of $(---) \alpha-M e D A,(\cdots \cdot)$ MDA and (-) 3-O-Me- $\alpha-M e D A$. Scan rate $5 \mathrm{mVs}^{-1}$.

Table 1. Redox Potential Values of MDMA and Its Metabolites

\begin{tabular}{llc}
\hline \multicolumn{1}{c}{ compound } & peak & $E_{\mathrm{p}} / \mathrm{V}$ vs Ag/AgCl \\
\hline$\alpha-M e D A(\mathbf{1 9})$ & I & 0.16 \\
& II & 0.89 \\
6-OH- $\alpha-M e D A ~(20)$ & I & -0.11 \\
& II & 1.05 \\
$N-M e-\alpha-M e D A ~(21)$ & I & 0.16 \\
& II & 1.25 \\
3-O-Me- $\alpha-M e D A ~(13)$ & I & 0.43 \\
MDMA (16) & II & 1.15 \\
& I & 1.06 \\
MDA (11) & II & 1.27 \\
& I & 1.07
\end{tabular}

reactive with respect to nucleophiles. The quinones can undergo an intracyclization process through the amine group of the sidechain, as an available nucleophile, leading to the formation of leucoaminochromes. Subsequently, these heterocyclic compounds can be easily oxidized to aminochromes. Moreover, the high predisposition to oxidation of these catecholic compounds, traduced by its redox potential, can also result in its autoxidation, leading to the formation of extracellular hydrogen peroxide and consequently to an increase in cytotoxicity.

\section{Conclusion}

The obtained data clearly indicate that some of the metabolites of MDMA cause stronger effects on PC12 cells than the parent compound, as shown by the analysis of their cytotoxic profiles. Given the large ammount of data implicating MDMA in neurodegeneration, the present results support the hypothesis that the mechanism of neurotoxicity can be related with biotransformation after the administration of the drug.

Although $N$-Me- $\alpha$-MeDA, 6-OH- $\alpha-M e D A$, and $\alpha-M e D A$ have not been undoubtedly established as in vivo neurotoxic metabolites of MDMA, it was demonstrated that these metabolites can account for the toxic properties of this drug. Note that $N$-Me- $\alpha-M e D A$, a metabolite that attains human plasma concentrations similar to those of MDMA (58), was the most toxic metabolite, a result that is in agreement with toxicological data obtained in cardiomyocytes and hepatocytes $(9,59)$. It is possible that adducts of these catecholic-containing compounds and major oxidative metabolites of MDMA could be generated and participate in its toxic effects $(60-62)$.

Comparing the cytotoxicity of $6-\mathrm{OH}-\alpha-\mathrm{MeDA}$ and $\alpha-\mathrm{MeDA}$, we conclude that the introduction of an hydroxyl group at the 


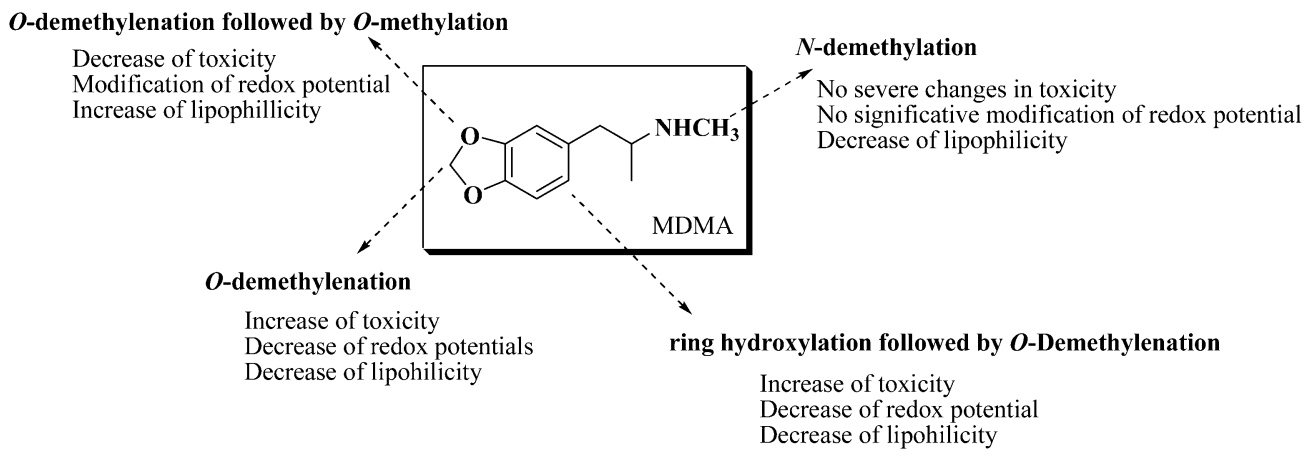

Figure 9. Consequences of structural modifications on toxicity and physicochemical properties of "ecstasy" (MDMA) and its metabolites.

ortho position to the amine side chain leads to an increase in cytotoxic properties. 6-OH- $\alpha-\mathrm{MeDA}$ was previously described as neurotoxic because it has structural similarities with 6-hydroxydopamine, a potent neurotoxin that causes long-term alterations in central monoaminergic systems $(13,19)$.

All compounds that possess a substituent in the catechol group seem to be less toxic than those with free aromatic hydroxyl groups. The ability of these latter compounds to form reactive $o$-quinones, leading to the formation of reactive species, is thought to represent a critical step in their toxicity, as suggested by previous studies $(63,64)$. Furthermore, the oxidation of the metabolites to their respective aminochromes, which are toxic, must also be taken in consideration (9). Electrochemical results fully support and explain the differences observed in terms of the cytotoxicity of the compounds.

N-Methylation enhances cytotoxicity on PC12 cells. In contrast, O-methylation of the catecholamine-type compounds seems to be a detoxification step in the metabolism of MDMA because the resulting compound (3-O-Me- $\alpha-\mathrm{MeDA}$ ) is significantly less toxic than the parent compound and the catecholic precursors that will undergo O-methylation by the action of COMT.

It is important to notice that the experimental $\mathrm{IC}_{50}$ values obtained in the present work (ranging from 150 to $7000 \mu \mathrm{M}$ ) are in agreement with other similar published in vitro studies $(59,61,62)$, particularly for the more toxic metabolites.

It was undoubtedly established that metabolism leads to changes of the redox potential of the parent compound. However, the authors believe that another physicochemical parameter, namely, lipophilicity, also contributes to its toxicity because a correlation was found between the partition coefficients of the metabolites and their toxicity as depicted in Figure 9.

The data on chromatin fragmentation/condensation reveal that the majority of MDMA metabolites significantly increase cell death by apoptosis. Programmed cell death was previously proposed to be involved in the neurotoxic effects of MDMA because the drug induces apoptosis on serotonergic and neocortical neurons $(36,37)$. If one compares the metabolites and the drugs used recreationally (MDMA and MDA), the overall effects of the compounds as apoptosis inducers are quite similar, and their toxic effects in undifferentiated PC12 cells seem to be associated with the induction of apoptotic cell death. Nevertheless, it is important to note that some metabolites also led to significant death by necrosis. Accordingly, further experimental approaches are needed to clarify the precise cytotoxic mechanisms.

Systemic metabolism of MDMA seems to be needed for the occurrence of neurotoxicity, but the nature of any putative toxic metabolite is still unknown. Because drug metabolites are usually more hydrophilic than their parent drug, specific transporters are presumably needed to take up the neurotoxic metabolite into the brain $(10,23)$. These results provide evidence that the metabolism of MDMA is a key factor for its toxicity and may prove to be useful in elucidating the amphetaminelike drug's putative activities.

Acknowledgment. N.M. and T.O. acknowledge financial support from FCT - Ph.D. fellowships PRAXIS XXI/BD/18520/ 98 and SFRH/BD/10910/2002. N.M. also acknowledges FCTI\&D N ${ }^{\circ} 226 / 94$ and POCTI (QCA III) for their support.

\section{References}

(1) Strote, J., Lee, J. E., and Wechsler, H. (2002) Increasing MDMA use among college students: Results of a national survey. J. Adolesc. Health 30, 64-72.

(2) Schifano, F., Oyefeso, A., Corkeri, J., Cobain, K., Jambert-Gray, R., Martinotti, G., and Ghodse, A. H. (2003) Death rates from ecstasy (MDMA, MDA) and polydrug use in England and Wales 1996-2002. Hum. Psychopharmacol. Clin. Exp. 18, 519-524.

(3) Meyer, J. S., Grande, M., Johnson, K., and Ali, S. F. (2004) Neurotoxic effects of MDMA ("ecstasy") administration to neonatal rats. Int. J. Dev. Neurosci. 22, 261-271.

(4) Cunningham, M. (1997) Ecstasy-induced rhabdomyolysis and its role in the development of acute renal failure. Intensive Crit. Care Nurs. 13, 216-223.

(5) Montiel-Duarte, C., Ansorena, E., López-Zabalza, M. J., Cenarruzabeitia, E., and Iraburu, M. J. (2004) Role of reactive oxygen species, glutathione and NF- $\kappa \mathrm{B}$ in apoptosis induced by 3, 4-methylenedioxymethamphetamine ("Ecstasy") on hepatic stellate cells. Biochem. Pharmacol. 47, 1151-1156.

(6) O'Cain, P. A., Hletko, S. B., Ogden, B. A., and Varner, K. J. (2000) Cardiovascular and sympathetic responses and reflex changes elicited by MDMA. Physiol. Behav. 70, 141-148.

(7) Testa, B., and Soine, W. (2003) Principles of Drug Metabolism. In Burger's Medicinal Chemistry and Drug Discovery, (Abraham, D. J., Ed.) 6th ed., Vol. 2, pp 431-498, Wiley-Interscience, Hoboken, NJ.

(8) Forsling, M. L., Fallon, J. K., Shah, D., Tilbrook, G. S., Cowan, D. A., Kicman, A. T., and Hutt, A. J. (2002) The effect of 3, 4-methylenedioxymethamphetamine (MDMA, "ecstasy") and its metabolites on neurohypophysial hormone release from the isolated rat hypothalamus. Br. J. Pharmacol. 135, 649-656.

(9) Carvalho, M., Remião, F., Milhazes, N., Borges, F., Fernandes, E., Monteiro, M. C., Gonçalves, M. J., Seabra, V., Amado, F., Carvalho, F., and Bastos, M. L. (2004) Metabolism is required for the expression of Ecstasy-induced cardiotoxicity in vitro. Chem. Res. Toxicol. 17, 623-632.

(10) Monks, T. J., Jones, D. C., Bai, F., and Lau, S. S. (2004) The role of metabolism in 3, 4- $( \pm)$-methylenedioxyamphetamine and 3, 4- $( \pm)$ methylenedioxymethamphetamine (ecstasy) toxicity. Ther. Drug Monit. 26, 132-136.

(11) Lim, H. K., and Foltz, R. L. (1988) In vivo and in vitro metabolism of 3,4-(methylenedioxy)methamphetamine in the rat: Identification of metabolites using an ion trap detector. Chem. Res. Toxicol. 1, 370378.

(12) Lim, H. K., and Foltz, R. L. (1991) Ion trap tandem mass spectrometric evidence for the metabolism of 3, 4-(methylenedioxy)methamphetamine to the potent neurotoxins 2,4,5-trihydroxymethamphetamine and 2,4,5-trihydroxyamphetamine. Chem. Res. Toxicol. 4, 626-632.

(13) Ma, S., Lin, L., Raghavan, R., Cohenour, P., Lin, P. Y. T., Bennett, J., Lewis, R. J., Enwall, E. L., Kostrzewa, R., Lehr, R. E., and Blank, C. L. (1995) In vivo and in vitro studies on the neurotoxic potential of 6-hydroxydopamine analogs. J. Med. Chem. 38, 4087-4097. 
(14) Hayes, J., Tipton, K. F., Bianchi, L., and Della Corte, L. (2001) Complexities in the neurotoxic actions of 6-hydroxydopamine in relation to the cytoprotective properties of taurine. Brain Res. Bull. $55,239-245$.

(15) Colado, M. I., Williams, J. L., and Green, A. R. (1995) The hyperthermic and neurotoxic effects of "ecstasy" (MDMA) and 3, 4-methylenedioxyamphetamine (MDMA) in the Dark Agouti (DA) rat, a model of the CYP2D6 poor metabolizer phenotype. $\mathrm{Br} . \mathrm{J}$. Pharmacol. 115, 1281-1289.

(16) Armstrong, B. D., and Noguchi, K. K. (2004) The neurotoxic effects of 3, 4-methylenedioxymethamphetamine (MDMA) and methamphetamine on serotonin, dopamine, and GABA-ergic terminals: An invitro autoradiographic study in rats. Neurotoxicology 25, 905-914.

(17) Itzhak, Y., and Achat-Mendes, C. (2004) Methamphetamine and MDMA (ecstasy) neurotoxicity: 'of mice and men'. IUBMB Life 56, 249-255.

(18) Johnson, M., Elayan, I., Hanson, G. R., Foltz, R. L., Gibb, J. W., and Lim, H. K. (1992) Effects of 3, 4-dihydroxymethamphetamine and 2 , 4, 5-trihydroxymethamphetamine, two metabolites of 3, 4-methylenedioxymethamphetamine, on central serotonergic and dopaminergic systems. J. Pharmacol. Exp. Ther. 261, 447-453.

(19) Zhao, Z., Castagnoli, N., Jr., Ricaurte, G. A., Steele, T., and Martello, M. (1992) Synthesis and neurotoxicological evaluation of putative metabolites of the serotonergic neurotoxin 2-(methylamino)-1-[3,4(methylenedioxy)phenyl]propane [(methylenedioxy)methamphetamine] Chem. Res. Toxicol. 5, 89-94.

(20) Bai, F., Lau, S. S., and Monks, T. J. (1999) Glutathione and $\mathrm{N}$-acetylcysteine conjugates of $\alpha$-methyldopamine produce serotonergic neurotoxicity: Possible role in methylenedioxyamphetaminemediated neurotoxicity. Chem. Res. Toxicol. 12, 1150-1157.

(21) Ricaurte, G., Bryan, G., Strauss, L., Seiden, L., and Schuster, C. (1985) Hallucinogenic amphetamine selectively destroys brain serotonin nerve terminals. Science 229, 986-988.

(22) Ricaurte, G. A., Martello, A. L., Katz, J. L., and Martello, M. B. (1992) Lasting effects of $( \pm) 3,4$-methylenedioxymethamphetamine (MDMA) on central serotonergic neurons in nonhuman primates: Neurochemical observations. J. Pharmacol. Exp. Ther. 261, 616-622.

(23) Lyles, J., and Cadet, J. L. (2003) Methylenedioxymethamphetamine (MDMA, ecstasy) neurotoxicity: Cellular and molecular mechanisms. Brain Res. Rev. 42, 155-168.

(24) Colado, M. I., Camarero, J., Mechan, A. O., Sanchez, V., Esteban, B., Elliot, J. M., and Green, A. R. (2001) A study of the mechanisms involved in the neurotoxic action of 3, 4-methylenedioxymethamphetamine (MDMA, 'ecstasy') on dopamine neurones in mouse brain. $\mathrm{Br}$. J. Pharmacol. 134, 1711-1723.

(25) Colado, M. I., O'Shea, E., and Green, A. R. (2004) Acute and longterm effects of MDMA on cerebral dopamine biochemistry and function Psychopharmacology 173, 249-263.

(26) Davidson, C., Gow, A. J., Lee, T. H., and Ellinwood, E. H. (2001) Methamphetamine neurotoxicity: necrotic and apoptotic mechanisms and relevance to human abuse treatment. Brain Res. Rev. 36, 1-22.

(27) Jiménez, A., Jordá, E. G., Verdaguer, E., Pubill, D., Sureda, F. X., Canudas, A. M., Escubedo, E., Camarasa, J., Camins, A., and Pallàs, M. (2004) Neurotoxicity of amphetamine derivatives is mediated by caspase pathway activation in rat cerebellar granule cells. Toxicol. Appl. Pharmacol. 196, 223-234.

(28) Jayanthi, S., Ladenheim, B., Andrews, A. M., and Cadet, J. L. (1999) Overexpression of human copper/zinc superoxide dismutase in transgenic mice attenuates oxidative stress caused by methylenedioxymethamphetamine (ecstasy). Neuroscience 91, 379-1387.

(29) Esteban, B., O'Shea, E., Camarero, J., Sanchez, V., Green, A. R., and Colado, M. I. (2001) 3,4-Methylededioxymethamphetamine induces monoamino release, but not toxicity, when administered centrally at a concentration occuring following a peripherally injected neurotoxic dose. Psychopharmacology 154, 251-260.

(30) McCann, U., and Ricaurte, G. A. (1991) Major metabolites of ( \pm )3, 4-methylenedioxyamphetamine (MDA) do not mediate its toxic effects on brain serotonin neurons. Brain Res. 545, 279-282.

(31) Yeh, S. Y., and Hsu, F.-L. (1991) The neurochemical and stimulatory effects of putative metabolites of 3,4-methylenedioxyamphetamine and 3,4-methylenedioxymethamphetamine in rats. Pharmacol. Biochem. Behav. 39, 787-790.

(32) Elayan, I., Gibb, J. W., Hanson, G. R., Foltz, R. L., Lim, H. K., and Johnson, M. (1992) Long-term alteration in the central monoaminergic systems of the rat by 2,4,5-trihydroxyamphetamine but not by 2-hydroxy-4,5-methylenedioxymethamphetamine or 2-hydroxy-4,5methylenedioxyamphetamine. Eur. J. Pharmacol. 221, 281-288.

(33) Greene, L. A., and Tischler, A. S. (1982) PC12 pheochromocytoma cultures in neurobiological research. Adv. Cell. Neurobiol. 3, 373414.

(34) Shafer, T. J., and Atchison, W. D. (1991) Transmitter, ion channel and receptor properties of pheochromocytoma (PC12) cells: A model for neurotoxicological studies. Neurotoxicology 12, 473-492.
(35) Lein, P., Silbergeld, E., Locke, P., and Goldberg, A. M. (2005) In vitro and other alternative approaches to developmental neurotoxicity testing (DNT). Environ. Toxicol. Pharmacol. 19, 735-744.

(36) Simantov, R., and Tauber, M. (1997) The abused drug MDMA (ecstasy) induces programmed death of human serotonergic cells. FASEB J. 11, 141-146.

(37) Stumm, G., Schlegel, J., Schäfer, T., Würz, C., Mennel, H. D., Krieg, J.-C., and Vedder, H. (1999) Amphetamines induce apoptosis and regulation of bcl-x splice variants in neocortical neurons. FASEB $J$ 13, 1065-1072.

(38) Parker, M. A., Marona-Lewicka, D., Kurrasch, D., Shulgin, A. T., and Nichols, D. E. (1998) Synthesis and pharmacological evaluation of ring-methylated derivatives of 3, 4-(methylenedioxy)amphetamine (MDA). J. Med. Chem. 41, 1001-1005.

(39) Naito, Y., Sugiura, M., Yamaura, Y., Fukaya, C., Yokoyama, K., Nakagawa, Y., Ikeda, T., Senda, M., and Fujita, T. (1991) Quantitative structure-activity relationship of catechol derivatives inhibiting 5-lipoxygenase. Chem. Pharm. Bull. 39, 1736-1745.

(40) Johnson, M. P., Frescas, S. P., Oberlender, R., and Nichols, D. E. (1991) Synthesis and pharmacological examination of 1-(3-methoxy4-methylphenyl)-2-aminopropane and 5-methoxy-6-methyl-2-aminoindan: Similarities to 3,4-(methylenedioxy)methamphetamine (MDMA) J. Med. Chem. 34, 1662-1668.

(41) Monte, A. P., Marona-Lewicka, D., Cozzi, N. V., and Nichols, D. E. (1993) Synthesis and pharmacological examination of benzofuran, indan, and tetralin analogues of 3,4-(methylenedioxy)amphetamine. J. Med. Chem. 36, 3700-3706.

(42) Gairaud, C. B., and Lappin, G. R. (1953) The synthesis of $\omega$-nitrostyrenes. J. Org. Chem. 18, 1-3.

(43) Morgan, P. H., and Beckett, A. H. (1975) Synthesis of some $\mathrm{N}$-oxygenated products of 3,4-dimethoxyamphetamine and its $\mathrm{N}$-alkyl derivatives. Tetrahedron 31, 2595-2601.

(44) Milhazes, N., Borges, F., Calheiros, R., and Marques, M. P. M. (2004) Identification of synthetic precursors of amphetamine-like drugs using Raman spectroscopy and $a b$ initio calculations: $\beta$-Methyl- $\beta$-nitrostyrene derivatives. Analyst 129, 1106-1117.

(45) Ensslin, H. K., Maurer, H. H., Gouzoulis, E., Hermle, L., and Kovar, K.-A. (1996) Metabolism of racemic 3,4-methylenedioxyethylamphetamine in humans: Isolation, identification, quantification, and synthesis of urinary metabolites. Drug Metab. Dispos. 24, 813-820.

(46) Marshall, K. S., and Castagnoli, N. (1973) Absolute configuration of $\alpha$-methyldopamine formed metabolically from $\alpha$-methyldopa in man J. Med. Chem. 16, 266-270.

(47) Chavdarian, C. G., Karashima, D., Castagnoli, N., and Hundley, H. K. (1978) Oxidative and cardiovascular studies on natural and synthetic catecholamines. J. Med. Chem. 21, 548-554.

(48) de Boer, D., Tan, L. P., Gorter, P., van de Wall, R. M. A., Kettenesvan den Bosch, J. J., Bruijn, E. A., and Maes, R. A. A. (1997) Gas chromatographic/mass spectrometric assay for profiling the enantiomers of 3,4-methylenedioxymethamphetamine and its chiral metabolites using positive chemical ionization ion trap mass spectrometry. J. Mass Spectrom. 32, 1236-1246.

(49) Bartholow, R. M., and Walaszek, E. J. (1976) 2,3-Dihydroxyphenethanolamine as an adrenergic agent. J. Med. Chem. 19, 189-190.

(50) Oliveira, M. T., Rego, A. C., Morgadinho, M. T., Macedo, T. R. A., and Oliveira, C. R. (2002) Toxic effects of opioid and stimulant drugs on undifferentiated PC12 cells. Ann. N.Y. Acad. Sci. 965, 487496.

(51) Mosmann, T. (1983) Rapid colorimetric assay for cellular growth and survival: Application to proliferation and cytotoxicity assays. $J$. Immunol. Methods 65, 55-63.

(52) Nicotera, P., and Melino, G. (2004) Regulation of the apoptosisnecrosis switch. Oncogene 23, 2757-2765.

(53) Calheiros, R., Milhazes, N., Borges, F., and Marques, M. P. M. (2004) $\beta$-Nitrostyrene derivatives - a conformational study by combined Raman spectroscopy and ab initio MO calculations. J. Mol. Struct. 692, 91-106

(54) Greene, T. W., and Wuts, P. G. M., Eds. (1999) Protective Groups in Organic Synthesis, 3rd ed., John Wiley \& Sons, Inc., NY.

(55) Fornai, F., Lenzi, P., Frenzilli, G., Gesi, M., Ferrucci, M., Lazzeri, G., Biagioni, F., Nigro, M., Falleni, A., Giusiani, M., Pellegrini, A. Blandini, F., Ruggieri, S., and Paparelli, A. (2004) DNA damage and ubiquitinated neuronal inclusions in the substantia nigra and striatum of mice following MDMA (ecstasy). Psychopharmacology (Berlin) $173,353-363$

(56) Hanrott, K., Gudmunsen, L., O’Neill, M. J., and Wonnacott, S. (2006) 6-Hydroxydopamine-induced apoptosis is mediated via extracellular auto-oxidation and caspase 3-dependent activation of protein kinase C $\delta$. J. Biol. Chem. 281, 5373-5382.

(57) Ricaurte, G. A., Yuan, J., and McCann, U. D. (2000) ( \pm )3, 4-Methylenedioxymethamphetamine ('ecstasy')-induced serotonin neurotoxicity: studies in animals. Neuropsychobiology 42, 5-10. 
(58) Segura, M., Ortuño, J., Farré, M., McLure, J. A., Pujadas, M., Pizarro, N., Llebaria, A., Joglar, J., Roset, P. N., Segura, J., and de la Torre, R. (2001) 3, 4-Dihydroxymethamphetamine (HHMA). A major in vivo 3, 4-methylenedioxymethamphetamine (MDMA) metabolite in humans. Chem. Res. Toxicol. 14, 1203-1208.

(59) Carvalho, M., Remião, F., Milhazes, N., Borges, F., Fernandes, E., Carvalho, F., and Bastos, M. L. (2004) The toxicity of $N$-methyl$\alpha$-methyldopamine to freshly isolated rat hepatocytes is prevented by ascorbic acid and $N$-acetylcysteine. Toxicology 200, 193203.

(60) Miller, R. T., Lau, S. S., and Monks, T. J. (1995) Metabolism of 5 -(glutathione-S-yl)- $\alpha$-methyldopamine following intracerebroventricular administration to male Sprague-Dawley rats. Chem. Res. Toxicol. 8, 634-641.

(61) Carvalho, M., Hawsworth, G., Milhazes, N., Borges, F., Monks, T. J., Fernandes, E., Carvalho, F., and Bastos, M. L. (2002) Role of metabolites in MDA (ecstasy) induced nephrotoxicity: an in vitro study using rat and human renal proximal tubular cells. Arch. Toxicol. $76,581-588$

(62) Carvalho, M., Milhazes, N., Borges, F., Fernandes, E., Monks, T. J., Carvalho, F., and Bastos, M. L. (2004) Hepatoxicity of 3, 4-methylenedioxyamphetamine and $\alpha$-methyldopamine in isolated hepatocytes: formation of glutathione conjugates. Arch. Toxicol. 78, 1624.

(63) Bolton, J. L., Trush, M. A., Penning, T. M., Dryhurst, G., and Monks, T. J. (2000) Role of quinones in toxicology. Chem. Res. Toxicol. 13, 135-160.

(64) Chichirau, A., Flueraru, M., Chepelev, L. L., Wright, J. S., Willmore, W. G., Durst, T., Hussain, H. H., and Charron, M. (2005) Mechanism of cytotoxicity of catechols and a naphthalenediol in PC12-AC cells: the connection between extracellular autoxidation and molecular electronic structure. Free Radical Biol. Med. 38, 344-355.

TX060123I 